\title{
Fifty years of ecological changes: Regime shifts and drivers in a coastal Mediterranean lagoon during oligotrophication
}

\author{
Derolez Valerie ${ }^{1,}{ }^{*}$, Malet Nathalie ${ }^{2}$, Fiandrino Annie ${ }^{1}$, Lagarde Franck ${ }^{1}$, Richard Marion ${ }^{1}$, \\ Ouisse Vincent ${ }^{1}$, Bec Beatrice ${ }^{3}$, Aliaume Catherine ${ }^{3}$
}

\author{
${ }^{1}$ MARBEC, Univ Montpellier, CNRS, IRD, Ifremer, Sète, France \\ 2 Ifremer LERPAC/CO, 20600 Bastia, France \\ ${ }^{3}$ MARBEC, Univ Montpellier, CNRS, IRD, Ifremer, Montpellier, France \\ * Corresponding author : Valerie Derolez, email address : valerie.derolez@ifremer.fr
}

\begin{abstract}
:
Thau lagoon is a large Mediterranean coastal lagoons and it supports traditional shellfish farming activities. It has been subject to eutrophication leading to major anoxic events associated with massive mortalities of shellfish stocks. Since the 1970s, improvements have been made to wastewater treatment systems, which have gradually led to oligotrophication of the lagoon. The aim of our study was to determine how the decrease in nutrient inputs resulted in major ecological changes in Thau lagoon, by analysing five decades of time-series (1970-2018) of observations on pelagic and benthic autotrophic communities. We were able to identify two periods during the oligotrophication process. Period 1 (19701992) was considered a eutrophic period, characterised by the shift from seagrass dominance to dominance of red macroalgae. Period 2 (1993-2018), characterised by improved eutrophication status, was further divided into three: a transition phase (1993-2003) during which the water column continued to recover but the benthic community lagged behind in recovery and in partial resilience; a regime shift (2003-2006), after which the water column became oligotrophic and seagrass began to recover (20072018). Considering anoxia crises as indicators of ecosystem resilience and resistance, we used a generalised linear model to analyse meteorological and environmental data with the aim of identifying the triggers of summer anoxia over the study period. Among the meteorological variables studied, air temperature had the strongest positive effect, followed by the period and wind intensity (both negative effects) and by rainfall in July (positive effect). The risk of triggering anoxia was lower in period 2, evidence for the increasing resistance of the ecosystem to climatic stress throughout the oligotrophication process. At the ecosystem scale and in the long term perspective, the ecological gains related to oligotrophication are especially important in the context of climate change, with more frequent and severe heat waves predicted.
\end{abstract}




\section{Graphical abstract}

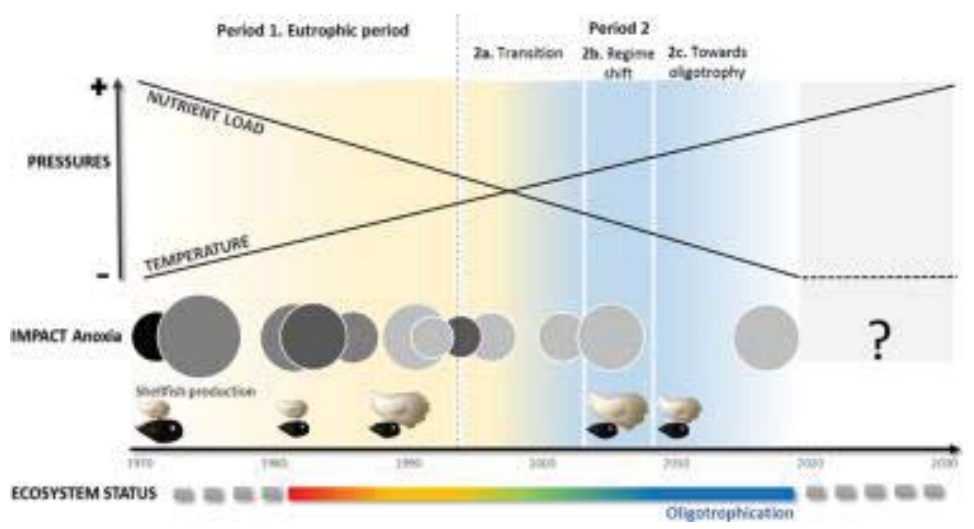

\section{Highlights}

This 5-decades study explains the oligotrophication trajectory of a coastal lagoon. The decrease in nutrient inputs resulted in ecological changes in pelagic \& benthic communities. A eutrophic period, a transition phase \& a regime shift characterised recovery. The main triggers of summer anoxia were air temperature and eutrophication status. Oligotrophication has made the ecosystem more resistant to the threat of heat waves.

Keywords : Eutrophication, Resilience, Anoxia, Climate change, Shellfish, Thau 


\section{Introduction}

Eutrophication is one of the most severe anthropic pressures faced by coastal ecosystems (de Jonge and Elliott, 2001; Nixon, 1995). Coastal lagoons are particularly exposed to anthropogenic eutrophication because of their relative isolation from the sea, their close links with watersheds, and their geomorphological features which enable high biological productivity (Newton et al., 2014; PérezRuzafa et al., 2019b; Zaldívar et al., 2008). Anoxia is triggered by eutrophication and by hydro-climatic factors such as high temperatures, and can seriously affect ecosystem functioning and the provision of ecosystem services (Iriarte et al., 2014; Jager et al., 2018; Newton et al., 2018) as they lead to the collapse of aquatic communities (Elliott and Quintino, 2007; Friedrich et al., 2014).

Thau lagoon is one of the largest Mediterranean coastal lagoons and supports traditional fishery and shellfish farming and, more recently, tourism and recreational activities (Deslous-Paoli et al., 1998; Gangnery et al., 2001). At the beginning of the $20^{\text {th }}$ century, Thau lagoon was dominated by seagrass beds associated with gastropods, while bare bottom areas were dominated by bivalves (Calvet, 1910). Since the 1960s, facing the exponential growth of the human population in the French Mediterranean coastal region and the resulting increase in anthropogenic inputs, Thau lagoon has suffered eutrophication and degradation of water quality (La Jeunesse and Elliott, 2004; Picot et al., 1990; Souchu et al., 2010). Among the ecological and socio-economic impacts of this degradation, eutrophication caused major anoxic events leading to massive mortality of shellfish stocks with significant economic impacts (Chapelle et al., 2000a; Souchu et al., 1998).

In the 1970s, improvements were made to waste-water treatment systems in the watershed. Ever since, a decrease in nutrient inputs to Thau lagoon has been recorded (Deslous-Paoli et al., 1998; La Jeunesse et al., 2002), reinforced in the late 2000s by the European regulations (EC 1991a; 1991b and 2000), which gradually led to the oligotrophication of the ecosystem (Bec et al., 2011; Collos et al., 2009). In our study, « oligotrophication » refers to the process associated with the depletion of nutrient in aquatic ecosystems, as used in other studies analysing the process of recovery of coastal or freshwater ecosystems after a decrease in nutrient loads (De Wit et al., 2020; Kamenir and Morabito, 2009; Mozetič et al., 2010). The recovery of the ecosystem was associated with a significant decrease in phytoplankton biomass, linked to a decrease in diatom abundance, and to a taxonomic shift in the microphytoplankton community, raising shellfish farmers' concerns about the limit of the lagoon's carrying capacity (Gowen et al. 2015; Derolez et al., 2020). In parallel, climate forcings in the 
Mediterranean region changed between the 1970s to the 2010s, with an increase in mean air temperature and in the frequency of summer heat waves, and a decrease in the frequency of wet years (Derolez et al., 2020; Jouzel et al. 2014). This raised the hypothesis that the shift in phytoplankton communities could be the result of the effects of a reduction in nutrient inputs combined with climatic-related variables.

Oligotrophication has only recently been characterised in coastal lagoons and existing studies mainly focus on a single community of primary producers: phytoplankton (Collos et al., 2009; Derolez et al., 2020; Leruste et al., 2016) or macrophytes (Le Fur et al., 2019; Tsiamis et al., 2013). Some of these studies showed that oligotrophication can lead to significant community shifts: from the dominance of diatoms to that of Chlorella-like algae and dinophytes (Leruste et al., 2016) and from the dominance of opportunistic species to that of perennial macrophyte species (Le Fur et al., 2019; Tsiamis et al., 2013). However, few studies have described coastal lagoons at the ecosystem level and over a long period to identify ecological changes (Pasqualini et al., 2017; Pérez-Ruzafa et al., 2019a). In coastal lagoons, assessing ecological status regarding eutrophication requires data on both pelagic and benthic compartments, as recommended by several authors (Newton et al. 2003; Zaldivar et al. 2008), most of which are identified in the Water Framework Directive (WFD) (EC, 2000): nutrients in the water column, phytoplankton biomass and abundance, macrophyte abundance and composition, and finally nutrients and organic matter in the sediment. However, regarding the dynamics of ecosystems recovery under global change, integrated long-term studies are needed to better understand the trajectories of lagoons focused on (i) changes in the ecosystem status, (ii) the capacity of ecosystems to withstand changes during environmental stresses (hereafter referred to as "resistance"), and (iii) their ability to return to predisturbance levels (hereafter referred to as "resilience") (Elliott et al., 2007; Gladstone-Gallagher et al., 2019).

The aim of the present study was first to determine how the decrease in nutrient inputs has resulted in ecological changes in the Thau lagoon ecosystem, by analysing five decades of time-series (19702018) of observations of the pelagic (nutrients and phytoplankton in the water column) and benthic (macrophytes and sediment) compartments. We hypothesise that the process of oligotrophication has led to ecosystem regime shifts and to changes in the drivers of summer anoxia, making the ecosystem more resistant to the threat of climate change. Considering anoxia crises as indicators of ecosystem 
resilience and resistance, we then analysed meteorological data, eutrophication status and shellfish production to identify the triggers of summer anoxia over the 49-year period.

\section{Materials and methods}

\subsection{Study site}

Thau lagoon is a microtidal restricted coastal lagoon, connected to the Mediterranean Sea through two permanent inlets, one of which is the Sète channel located in the north-east, which is responsible for $90 \%$ of sea water exchanges (Fig. 1) (Fiandrino et al., 2017). The lagoon covers an area of $68 \mathrm{~km}^{2}$, its mean depth is $4 \mathrm{~m}$ (Fiandrino et al., 2017). A depth gradient is observed from the south-west mean depth: $3.3 \mathrm{~m}$ ) to the north-east (mean depth: $5.2 \mathrm{~m}$ ) of the lagoon (Souchu et al., 2001). The Thau watershed covers $280 \mathrm{~km}^{2}$ and is drained by tributaries with intermittent flows and two permanent rivers (La Jeunesse et al., 2015). Approximately half the watershed's permanent population $(103,500$ inh. in 2015, INSEE 2016) is located in the city of Sète (La Jeunesse et al., 2015).

Shellfish farming structures cover $20 \%$ of the lagoon surface in three cultivation zones (Fig. 1). The shellfish reared are mussels Mytilus galloprovincialis (M. galloprovincialis) and Pacific oyster, Crassostrea gigas (C. gigas), whose production accounted for about $10 \%$ of total French oyster production in the 2000s (Gangnery et al., 2003).

\subsection{Biological and meteorological monitoring}

The biological and meteorological data used in our study, the associated spatial and temporal strategy and the references when available, are described in detail in Table A1.

\subsubsection{Hydrological, nutrients and phytoplankton time series}

From 1999 to 2018, water samples were collected monthly in summer (June, July and August), which is the maximum primary production period in Mediterranean lagoons (Bec et al., 2011; Souchu et al., 2010), at three stations: TANG, TE and TW (Fig. 1A). Samples were collected a minimum of three days after any period when wind speed exceeded $12.5 \mathrm{~m} \mathrm{~s}^{-1}$ to allow sediments to stabilise. Temperature $\left(T E M P,{ }^{\circ} \mathrm{C}\right)$, salinity $(S A L)$ and dissolved oxygen $\left(O 2, \mathrm{mg} \mathrm{L}^{-1}\right)$ were recorded in situ with field sensors. At each station, on each sampling occasion, one water sample was collected in a $1 \mathrm{~L}$ polypropylene bottle one metre below the surface for laboratory analyses, according to Souchu et al. (2010). 
Laboratory analyses were carried out to measure dissolved and total nutrient concentrations $(\mu \mathrm{M})$ : dissolved inorganic phosphorus $($ DIP $)$, dissolved inorganic nitrogen $\left(D I N=\mathrm{NH}_{4}{ }^{+}+\mathrm{NO}_{3}{ }^{-}+\mathrm{NO}_{2}{ }^{-}\right)$, total nitrogen $(T N)$ and total phosphorus (TP). Nutrients were analysed using the standard protocols (Aminot and Kérouel, 2007) described in Souchu et al. (2010). Turbidity (TURB, NTU) was measured in the laboratory with a HACH $2100 \mathrm{~N}$ IS sensor according to ISO 7027.

From 1972 to 1993, DIP was analysed in water samples collected monthly in summer at ZA station, located in the shellfish farming area in the north-east part of the lagoon (Fig. 1A) (Collos et al., 2009; Derolez et al., 2020; Souchu et al., 1998).

Phytoplankton analyses were performed according to Bec et al. (2011). Chlorophyll a concentrations

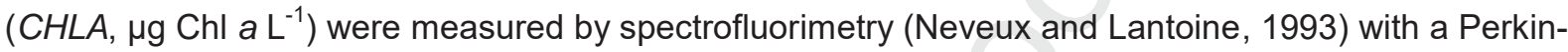
Elmer L650. Based on cytometric analyses, different size classes of phytoplankton were identified and counted with a FACSCalibur flow cytometer: autotrophic picoeukaryotes $(\leq 3 \mu \mathrm{m})$ and nanophytoplankton $\left(>3 \mu \mathrm{m}\right.$ ) abundances (PEUK and NANO, $10^{6}$ cells $\mathrm{L}^{-1}$ ). Phycoerythrin-rich picocyanobacteria $\left(<1 \mu \mathrm{m}, P E-C Y A N, 10^{6}\right.$ cells $\left.\mathrm{L}^{-1}\right)$ were distinguished from other photosynthetic organisms by their strong orange fluorescence and light-scattering properties.

\subsubsection{Macrophyte and sediment time series}

Soft bottom macrophytes were monitored five times in June from 2003 to 2017 at 36 stations (Fig. 1A, Table A1). Data from four older samplings (1966 to 1998), collected using different sampling protocols and monitoring methods, were added to the macrophyte time series. Table A1 summarises the years of observation, the formats of the data and the sampling methods used for all macrophyte data. In the case of sampling carried out over several years to cover the entire surface of the lagoon, it was decided to refer to the year corresponding to the middle of the period (i.e. year 1966 for the sampling period 1963-1968, and year 1992 for the sampling period 1988-1994) in the results section 2.3.2. The methods applied in 1998 and from 2003 to 2017 are detailed in Le Fur et al. (2017).

Sediment was sampled at 28 stations in late spring or early summer in 1998, 2003, 2008 and 2014 (Fig. 1B). The top layer $(0-5 \mathrm{~cm})$ of sediment was collected with a sediment corer and then sifted through a 2-mm sieve (see Le Fur et al. (2019) for details). Mud content (\%) corresponded to the fraction with a diameter of less $<50 \mu \mathrm{m}$. Organic matter content $(O M$, expressed as $\%$ of dry sediment 
weight), total nitrogen $(T N)$ and total phosphorus $(T P)$ were analysed and were expressed in $\mathrm{g} \mathrm{kg}^{-1}$ and $\mathrm{mg} \mathrm{kg}^{-1}$ of dry sediment, respectively.

Data on Kjeldahl-N $(K N)$ and TP concentrations, analysed in sediment samples collected in 1987 at 30 stations, were taken from Péna and Picot (1991) and added to the sediment time series.

\subsubsection{Shellfish production}

Total annual oyster production, mussel production and total shellfish production data (in $10^{3} \mathrm{t}^{-1}$ ) were collected by the Departmental Direction of Maritime Affairs and gathered by Comps et al. (2000) and Gangnery (1998 \& 1999) for the period 1970-2000. Data for the years 2001, 2002 and 2003 were collected by Gangnery (2003). Production data for the period 2004 to 2018, were provided by the Departmental Directorate of Territories and the Sea (French acronym DDTM). The mussel species remained the same throughout the study period (M. galloprovincialis), but the oyster species changed in 1973 after the epizootic linked to an iridovirus which resulted in the disappearance of the Portuguese oyster Crassostrea angulata, which was replaced by the Pacific oyster (C. gigas) (Grizel and Héral 1991).

Given that anoxia events can cause significant mortality of the shellfish cultivated in the lagoon, the total shellfish production of the preceding year was used to estimate the stock exposed to anoxia in the summer of any given year (Q_shellfish_1). Data were transformed into binary variables with the following values: shellfish $=1$ for low production rates $(\leq 10000 \mathrm{t})$ and shellfish $=2$ for higher production (> $10000 \mathrm{t})$.

\subsubsection{Meteorological data}

Daily data on rainfall $(\mathrm{mm})$, air temperature $\left({ }^{\circ} \mathrm{C}\right)$ and wind intensity $\left(\mathrm{m} \mathrm{s}^{-1}\right)$ from 1970 to 2018 were collected from the Sète meteorological station (Météo-France station n³4301002) (Fig. 1A).

Summer air temperatures and wind intensities were averaged by month (June, July and August) (air_M, wind_M). Wind intensities were then standardised according to four periods determined by shifts in the raw time series corresponding to modifications to the sensors identified by Météo-France (January 1972, August 1996, January 2008) (wind_ST). 
Rainfall was cumulated in June, July and August (rainfall_6, rainfall_7, rainfall_8) corresponding to the summer months when anoxia occurrs, and from January to May (rainfall_1-5) corresponding to the winter and spring months preceding anoxia.

\subsection{Data processing and analyses}

\subsubsection{Hydrological, nutrient and phytoplankton time series}

Data collected in summer from 1999 to 2018 at the three stations TANG, TE and TW were averaged per year before performing an explanatory PCA analysis with nine variables (DIN, DIP, TP, TN, CHLA, PEUK, NANO, PE-CYAN and O2) (ade4 package in R). The phytoplankton variables were $\log _{10}$ transformed to normalise the data and reduce the effect of very high values. The three hydrological parameters (TEMP, SAL and TURB) were considered as illustrative variables in the PCA. K-means cluster analysis was then applied to identify years and stations with similar eutrophication patterns (vegan package in R). The optimal number of clusters was estimated based on the Calinski-Harabasz index (Calinski and Harabasz, 1974).

For the hydrological and phytoplankton variables (DIN, DIP, TP, TN, CHLA, PEUK, NANO, PE-CYAN, O2, TEMP, SAL, TURB and the ratio PE-CYAN/PEUK), Mann-Kendall tests (MK) were performed on the means calculated for each year from 1999 to 2018 to characterise the monotonic trends. To eliminate the effect of serial correlations on the MK test, we used the modification by effective sample size, computed with significant serial correlation coefficients (Hamed and Rao (1998), modifiedmk package in R). If the test was significant (i.e. p-values $<0.05$ ), the Theil-Sen's slope estimator was calculated (Sen, 1968). The correlation between water temperature and PE-CYAN was tested using Spearman's test.

In Thau lagoon, DIP is not considered to be the main limiting nutrient (Fouilland et al., 2002; Souchu et al., 2010) and its concentrations in water are well correlated with the inputs from human activities in the watershed (La Jeunesse and Elliott, 2004). Moreover, in summer, it has been shown that in deeper lagoons such as Thau, P loads from sediments are enhanced by high temperatures through the benthic remineralization process (Chapelle et al., 2000b; Souchu et al., 1998; Zilius et al., 2015). Finally, shellfish farming is known to contribute to summer remineralization (Chapelle et al., 2000a; Mazouni et al., 1996). For all these reasons, the summer concentration of DIP in the water column is a good indicator of eutrophication in the Thau lagoon. To analyse the changes in summer DIP 
concentrations in the water of Thau lagoon from 1970 to 2018, we pooled the data collected in summer at ZA and TE stations, located in the same well mixed zone according to Millet (1989) and Fiandrino et al. (2017). To avoid the impact of high temperatures and anoxia on DIP due to increased discharge from sediment (Chapelle et al., 2000b; Mazouni et al., 1996), data collected in the late summer (July and August) were removed from the dataset. Thus, DIP data collected in June (DIP_6) were modelled using LOESS (polynomial degree $=2$, smoothing degree $=0.75$ ). The first derivative of the modelled data was first used to identify the breaking points characterising changes in the slope in the curve. Then, the measured concentrations of DIP in June were compared with the threshold of the good status for DIP according to the WFD (DIP $\leq 1 \mu \mathrm{M}$; MTES, 2018), in order to identify the year after which this threshold was no longer exceeded. These two criteria were used to divide the time series into two contrasting periods in terms of eutrophication status: period 1 and period 2. We performed MK tests on the total time series and for both periods to characterise monotonic trends.

\subsubsection{Macrophyte community}

The phylum taxonomic scale was chosen to enable us to compare macrophyte data from the nine available surveys conducted between 1966 and 2018 (Table A1). The macrophytes were distributed in four groups: red algae (Rhodophyta), green algae (Chlorophyta), brown algae (Ochrophyta) and seagrass (Tracheophyta). An additional group corresponding to bare sediment was created for stations with no vegetation. For data whose measurements were sporadic, the percentage of cover or biomass was calculated for each group of macrophytes. The group with the highest percentage of cover was selected as "dominant". When the difference in the percentages between the first two groups was $\leq 2 \%$, both groups were considered to be dominant. This pre-treatment enabled comparison of data on dominant groups shown on the maps collected from 1966 to 1992. The first two most frequent genera in each group are given for each survey.

The spatial representation of the macrophyte was homogenised over the nine vegetation surveys in order to retrieve the data corresponding to the 36 benthic stations monitored in the five most recent surveys (Fig. 1). Concerning the three surveys conducted between 1986 and 1998, the macrophyte data were retrieved from $100 \mathrm{~m}$ buffer zones created around the 36 stations projected onto the three available maps. The publications used to construct the map of the 1960s consisted of a description of macrophyte distribution in the literature, without precise spatial coordinates. Consequently, we localised the information on the dominant species in the locations described in the literature. In the 
surveys carried out before 2003 , it was not possible to collect information from all 36 stations. The number of stations used for each survey is given in Table A1.

Finally, the proportion of stations with bare sediment (i.e. without vegetation) or dominated by each group of macrophytes was calculated for each period as follows: Proportion of stations dominated by group $i=$ number of stations dominated by group $i \div$ total number of stations considered.

\subsubsection{Sediments}

To characterise the monotonic trends of sediment variables we performed Mann-Kendall tests on the medians calculated for each survey (1998, 2003, 2008 and 2014 for mud, OM and TN and 1987, 1998, 2003, 2008 and 2014 for TP).

2.3.4. Occurrence and intensity of anoxia events, meteorological and environmental conditions

Information on the frequency and intensity of the summer anoxic crises which occurred between 1970 and 2018 was collected from the scientific and grey literature (Hamon et al., 2000; Trousselier and Deslous-Paoli, 2001; Ifremer, 2004; Ifremer, 2007; Lagarde, 2018a). Since the spatial and temporal strategies of $\mathrm{O}_{2}$ monitoring did not remain the same over the study period, we defined the occurrence of anoxia based on presence of white water caused by sulphur bacteria reoxidising the sulphur released in the water column (Minghelli-Roman et al., 2011), or on the presence of at least one measurement of $\mathrm{O}_{2}$ concentration $<0.05 \mathrm{mg} \mathrm{L}^{-1}$. The intensity of the anoxia crises was characterised according to their duration in months ( $\leq 1$ to 3 ) and to their maximum spatial extent: 1 (one of the shellfish farming areas), 2 (two of the shellfish farming areas), 3 (all three shellfish farming areas), 5 (the whole lagoon).

Out of the total of 147 summer months in the 1970-2018 period, 12 months were characterised by the onset of an anoxia crisis (anoxia $=1)$ and 135 months had no anoxia onset (anoxia $=0)$. In order to identify the meteorological and environmental conditions involved in the triggering of anoxia, a binomial generalised linear model (glm) (McCullagh and Nelder 1989) was built with the following eight variables:

- meteorological variables: air_M and wind_ST (summer monthly averages), rainfall_6, rainfall_7, rainfall_8 and rainfall_1-5 (cumulative rainfalls);

- eutrophication status: period (1 or 2); 
- shellfish production: shellfish (1: low or 2: high).

The Akaike information criterion (AIC) was used to select the significant variables and the odds ratios (OR) were calculated $\left(O R_{x}=e^{\beta x}\right.$, with $\beta_{x}$ the estimated coefficient for variable $\left.x\right)$ to evaluate the probability of triggering anoxia versus the probability of not triggering anoxia when modifying variables independently. The odds ratios provide information on the strength and direction of the association between the dependent and explanatory variables $(O R>1$ : increases the probability, $0 \leq O R<1$ : decreases the probability) (Schwarz, 1978, ggeffects in R). The performance of the glm was assessed by cross validation ( $70 \%$ for calibration, $30 \%$ for validation). The test datasets consisted of 100 observations randomly drawn from the 135 months with no anoxia; and from the 12 months characterised by the onset of anoxia. The receiver operating characteristic (ROC), which depends on specificity and sensitivity), and the area under the curve (AUC) were calculated for the 50 test datasets drawn randomly to estimate the average and standard deviation of this criterion (DeLong et al., 1998, Presence-Absence in R). According to AUC, a model is considered as not contributing ( $A \cup C=0.5$ ), not very informative $(0.5 \leq A \cup C<0.7)$, moderately informative $(0.7 \leq A \cup C<0.9)$, very informative $(0.9 \leq \mathrm{AUC}<1)$ or perfect $(\mathrm{AUC}=1)($ Swets, 1988) .

In addition, Kruskal-Wallis tests were performed on the following variables to identify significant differences in the characteristics of the two periods: air_M, wind_ST, rainfall_6, rainfall_7, rainfall_8, rainfall_1-5, DIP_6 and Q_shellfish_1.

\section{Results}

\subsection{Change in trophic status from eutrophication to oligotrophication}

\subsubsection{Water column}

The average summer concentrations of dissolved phosphorus measured in water ranged from $6.7 \mu \mathrm{M}$ in 1972 to $0.04 \mu \mathrm{M}$ in 2016-2017, with a median value of $0.9 \mu \mathrm{M}$, and they decreased monotonically and significantly over the study period (MK p<0.001, Theil-Sen's slope $\left.=-0.1 \mu \mathrm{M} \mathrm{y}{ }^{-1}\right)$ (Fig. 2).

When focusing on June observations, the concentrations of dissolved phosphorus ranged from $5.2 \mu \mathrm{M}$ in 1974 to $0.04 \mu \mathrm{M}$ in 2015-2017, with a median value of $0.3 \mu \mathrm{M}$, and they decreased monotonically and significantly over the study period (MK $p<0.001$, Theil-Sen's slope $=-0.1 \mu \mathrm{M} y^{-1}$ ) (Fig. 2, black dots). The slope of the time series modelled with LOESS revealed two breaks: the first in June 1991 
and the second in June 1993. Moreover, the threshold of good status according to WFD (DIP $\leq 1 \mu \mathrm{M})$ was no longer exceeded after June 1993, which made it possible to identify two contrasting periods based on the eutrophication status: period 1, from 1970 to 1992 and period 2, from 1993 to 2018. When considering data for each period separately, DIP concentrations also decreased significantly, but the median and the slope were higher in the first period (respectively, median=2.3 $\mu \mathrm{M}, \mathrm{MK}$ $p<0.001$ and Theil-Sen's slope $=-0.3 \mu \mathrm{M} \mathrm{y}^{-1} ;$ median $=0.1 \mu \mathrm{M}, \mathrm{MK} p=0.002$ and Theil-Sen's slope $=-$ $0.005 \mu \mathrm{M} \mathrm{y}^{-1}$ ).

PCA analysis of the data was performed on nine variables (DIN, DIP, TP, TN, CHLA, PEUK, NANO, PE-CYAN and O2) collected from 1999 to 2018, corresponding to PERIOD 2 defined based on eutrophic status. The PCA of this water column time series showed that the two first axes accounted for $52.6 \%$ of total variability ( $33.9 \%$ and $18.6 \%$ for axis 1 and axis 2 , respectively). The third axis, accounted for $14.4 \%$ of the variability and was positively correlated with $\mathrm{O} 2$ and negatively correlated with TN (Fig. A1.A). The first axis revealed a clear temporal structure, contrasting the earliest and the most recent years (Fig. 3B). This first axis was negatively correlated mainly with TP, DIP, PEUK, CHLA and DIN (Fig. 3A). The second axis was mainly defined by PE-CYAN abundances, with a high contribution of the years 2006 and 2003 (Fig. 3A). The temperature, considered as an illustrative variable in the PCA analysis, was correlated with the second axis and consequently with PE-CYAN. The third axis isolated the samples collected at TANG station (Fig. A1.C).

Among the three clusters identified by the Calinski-Harabasz index on the PCA, a first group, located on the left side of the PCA, grouped 23 samples collected from 1999 to 2008, with the years 1999 to 2001 and 2003 to 2005 only found in this cluster (Fig. 3B). On the right side of the PCA, the second cluster (29 samples) was characterised by low levels of nutrient and phytoplankton biomass and abundance and isolated the samples collected exclusively from 2007 to 2018 (Fig. 3B). Finally, the third cluster was isolated according to the third axis and grouped seven samples collected at TANG station in 2002, 2006, 2008 to 2011 and 2018 (Fig. A1.B and A1.C).

From 1999 to 2018, the phytoplankton community was marked by changes in chlorophyll a biomass and pico- and nano-phytoplankton abundances at TW-TE stations (averaged data) and TANG stations (Fig. 4). A significant decreasing trend was found for chlorophyll a biomass from 1999 to 2018 (respectively MK $p=0.003$ and $p=0.02$, Theil-Sen's slope $=-0.17 \mu \mathrm{g} \mathrm{L}^{-1}$ and $-0.15 \mu \mathrm{L} \mathrm{L}^{-1}$ ). Moreover, two phases are identifable in the evolution of CHLA: the period 1999-2006, when maximum values 
were reached (respectively 6.2 and $15.7 \mu \mathrm{g} \mathrm{L}^{-1}$ at TW-TE and TANG), and the period 2007-2018 characterised by lower values $\left(<2 \mu \mathrm{L}^{-1}\right)($ Fig. $4 \mathrm{~A})$.

Like chlorophyll a, picoeukaryote abundances revealed a decreasing trend (MK $p=0.006$ and 0.001 and Theil-Sen's slope $=-1.610^{6} \mathrm{~L}^{-1}$ and $-2.810^{6}$ cells $\mathrm{L}^{-1}$ at TW-TE and TANG stations respectively), with the exception of the maximum values reached in 2003 and 2004 (respectively $12010^{6}$ cells $\mathrm{L}^{-1}$ at TW-TE and $11310^{6}$ cells $\mathrm{L}^{-1}$ at TANG) (Fig. 4C). On the contrary, nanophytoplankton revealed no significant monotonic trend (MK p>0.05). Nanophytoplankton levels peaked in $2006\left(41.610^{6}\right.$ cells $\mathrm{L}^{-1}$ at TANG) and increased to reach a second maximum in 2011 (28.4 $10^{6}$ cells $\mathrm{L}^{-1}$ at TW-TE), then decreased and remained below $3.710^{6}$ cells $L^{-1}$ (Fig. 4B).

Changes in phycoerythrin-rich picocyanobacteria were contrasted, with no significant monotonic trend (MK p>0.05). PE-CYAN abundances exhibited three peaks in 2003, 2006 and 2018 (respectively 283.7, 295 and $282.310^{6}$ cells $\mathrm{L}^{-1}$ at TW-TE), associated with water temperatures above $25.6^{\circ} \mathrm{C}$ (Fig. 4D). Water temperatures and PE-CYAN abundances were significantly correlated at TW-TE stations (Spearman $p=0.002$, rho $=0.65$ ) but not at TANG station. Finally, the PE-CYAN/PEUK ratio increased significantly, from 0.01 in 1999 to 15.7 in 2018 at TW-TE (MK $p<0.001$ Theil-Sen's slope = 0.16), but not at TANG station.

Among the other hydrological parameters, decreasing monotonic trends were found for TP, DIP and DIN at TW-TE and TANG stations from 1999 to 2018 (Fig. A2.B, A2.D and A2.C) and for TN and O2 only at TW-TE stations (Fig. A2.A and A2.F). An increasing trend was found for TEMP only at TANG station (Fig. A2.H).

\subsubsection{Benthic compartment}

\section{a) Macrophyte composition}

The percentage of benthic stations not covered by soft bottom macrophytes tended to decrease from 1966 to 2017, with the highest percentages measured in the 1980s and 1960 s (28.6 and 22\%, respectively), and null values from 2011 on (Fig. 5).

The macrophyte community consisted mainly of seagrass beds in the $1960 \mathrm{~s}$, dominating coverage at $40 \%$ of the benthic stations (Fig.5). Seagrass cover declined between the 1960 s and the 1980 s in favour of red algae, which became the second dominant group after seagrass in 1986 and 1992 . The percentage of stations dominated by seagrass continued to decline until 2003 , when it reached its 
minimum (11.4\%), then increased from $15.4 \%$ in 2008 to $22.5 \%$ in 2011 and 2014 . After dominance by seagrass, red algae dominated the macrophyte community from 1998 to 2017 (between $42.5 \%$ of benthic stations were dominated by this group in 2011 and 2014 and 55.6\% in 2017).

Brown algae dominated $18 \%$ of the stations in 1966, but rarely dominated between 1986 and 2008 (0 to $15.4 \%$ of the benthic stations were dominated by this group); brown algae reached $22.5 \%$ to $25 \%$ between 2011 and 2017. The contribution of green algae to macrophyte cover was low to zero (in 2017) and did not change significantly over the study period (from $11.4 \%$ of benthic stations dominated by this group in 1966 and 2003 to $19.2 \%$ in 1999).

Regarding the composition of each group of macrophytes, seagrass beds were composed of two Zostera species: Zostera noltei and Z. marina, both species being observed in all samples collected from 1966 to 2017.

Red algae consisted of Polysophonia and Halopitys genera in 1966 (Dubois, 1972; Lauret, 1967 \& 1970). Then, Halopitys and Gracilaria genera were the two most frequent red algae observed in 1986 , 1992 and 1998 (Gerbal and Verlaque, 1995; Lauret, 1990 \& 1994; Verlaque, 2000). Gracilaria and Alsidium were the most frequent red algae in 2003 and Gracilaria and Polysiphonia in 2008 (Ifremer, 2004 \& 2007). Finally, from 2011 to 2017, Gracilaria and Halopitys again became the most frequent red algae, with a shift in dominance from Gracilaria to Halopitys in 2017 (Bouchoucha et al. 2019; Derolez et al. 2015; Ifremer 2009 \& 2012).

Codium genera was the only green algae listed in 1966, while Ulva and Monostroma genera were the most frequently observed green algae in 1986 (Dubois, 1972; Gerbal and Verlaque, 1995; Lauret, 1967 \& 1970). Ulva and Chaetomorpha were the most frequent genera in 1992 (Lauret, 1990 \& 1994). Finally, the most frequent green algae were Ulva and Cladophora in 2008 and 2011 and Chaetomorpha and Cladophora in 1998, 2003 and 2014 (Derolez et al. 2015; Ifremer 2004, 2009, \& 2012; Verlaque, 2000).

Cystoseira and Sargassum were the only brown algae genera listed in 1966 and 1998, respectively, whereas both genera were cited in 1986 (Dubois, 1972; Gerbal and Verlaque, 1995; Lauret, 1967 \& 1970). Colpomenia and Cutleria and Colpomenia and Cystoseira were the most frequently observed in 1998 and 2003, respectively, (Ifremer, 2004; Verlaque, 2000). Finally, Dictyota genera and the family 
Ectocarpaceae were the most frequent brown algae observed from 2008 to 2017 (Bouchoucha et al. 2019; Derolez et al. 2015; Ifremer 2009 \& 2012).

\section{b) Sediment}

Median concentrations of mud and organic matter in the surface sediment ranged from $61.8 \%$ in 1998 to $83.5 \%$ in 2008 and from $6.6 \%$ in 1998 to $13 \%$ in 2014 , respectively, but did not change significantly from 1998 to 2014 (MK p=0.67 and $p=0.051$, respectively) (Fig. A3-A and A3-B). On the contrary, a significant increasing trend was revealed for total nitrogen from 1998 to 2014, with medians ranging from 2.8 to $4.7 \mathrm{~g} \mathrm{~kg}^{-1}$ (MK p=0.001, Theil-Sen's slope $=0.54 \mathrm{~g} \mathrm{~kg}^{-1} \mathrm{y}^{-1}$ ) and confirmed from 1987 to 2014 when KN values measured in $1987\left(2.7 \mathrm{~g} \mathrm{~kg}^{-1}\right)$ were included (MK $p<0.001$, Theil-Sen's slope $=0.49 \mathrm{~g} \mathrm{~kg}^{-1} \mathrm{y}^{-1}$ ) (Fig. A3-C). In contrast to the other parameters, although the medians of total phosphorus did not show a monotonic trend from 1987 to 2014 (MK $p=0.81$ ), the maximum was reached in $2003\left(771 \mathrm{mg} \mathrm{kg}^{-1}\right)$ and the minimum in $2014\left(577 \mathrm{mg} \mathrm{kg}^{-1}\right)$ (Fig. A3-D).

\subsection{Changes in shellfish production}

Shellfish production varied significantly between 1970 and 2018 (Fig. 7). Total annual production ranged from $6650 \mathrm{t}$ in 1982 to $18000 \mathrm{t}$ in 2001 to 2003. Mussel production ranged from $1038 \mathrm{t}$ in 1990 to $11550 t$ in 1970 and dominated Thau shellfish production from 1970 to 1983 (45-93\% of total production). From 1972 to the 1990s, mussel production declined in favour of oyster production (Crassostrea angulata until 1972 and Crassostrea gigas ever since). Thus, oyster production has accounted for most shellfish production since 1983 (53 to 90\% of total production). Oyster production revealed two peaks: a first peak in 1994 (15 000 t) and a second peak during the period 2000-2008 (12 000 to 13000 t). In 2009, oyster production declined sharply due to the OsHV-1 $\mu$ var epizootic (Pernet et al., 2012). It slowly increased from 2012 to 2017, while remaining below 8000 t. Finally in 2018, oyster production again decreased to $6030 \mathrm{t}$.

Figure 6 also shows the years in which a summer anoxic event occurred (in grey). From 1970 to 2018, 12 anoxic events were recorded in the lagoon. About half of these crises occurred in the 1980s and 1990s. Some of these years were characterised by significant a decline in production (e.g. 1975, 1982, 1990, 1997, 2018), associated with shellfish mortalities.

\subsection{Triggering factors of summer anoxia}


Figure 7 shows the duration and spatial extent of summer anoxia in Thau lagoon from 1970 to 2018. The 1970 anoxia event lasted three months and the 1983 and 1994 anoxia events each lasted two months. The anoxia events in 1975, 1982, and 1987 lasted six weeks and the other anoxia events, between 1990 and 2018 lasted one month or less. The most extensive anoxia event occurred in 1975, when the entire lagoon was under hypoxic conditions (Troussellier and Deslous-Paoli, 2001). The 1982, 1983, 1990, 2006 and 2018 anoxia events affected all three shellfish farming areas, while the others affected only one or two. The duration and spatial extent of the seven anoxia events which occurred in period 1 (from 1970 to 1992) were greater than those of the five last anoxia events which occurred in period 2 (from 1993 to 2018) (respective median duration ranged from four to six weeks and the median spatial extent from two to three areas).

The Kruskal-Wallis tests performed to differentiate the characteristics of periods 1 and 2 were significant for the following variables ( $p$-values $<0.05$ ): mean monthly air temperature increased (air_M, median from 22.3 to $23.1^{\circ} \mathrm{C}$ ), rainfall from January to May and rainfall in June decreased (respectively rainfall_1-5: median from $253 \mathrm{~mm}$ to $219 \mathrm{~mm}$, rainfall_6: median from $21 \mathrm{~mm}$ to $16 \mathrm{~mm}$ ), the concentration of DIP in June decrased (DIP_6, median from 2.3 to $0.1 \mu \mathrm{M})$ and total annual shellfish production increased (Q_shellfish_1, median from $8.710^{3}$ to $13.410^{3} \mathrm{t} \mathrm{y}^{-1}$ ). The other three variables (wind_ST, rainfall_7, rainfall_8) did not differ significantly between the two periods.

Among the eight variables included in the glm predicting the triggering of summer anoxia, four were considered as significant based on the AIC: summer monthly averages of air temperature and wind intensity, rainfall in July and the period determined according to the eutrophication status (air_ $M$, wind_ST, rainfall_7 and period 2). According to the AUC criterion, the performance of this glm was good (mean=0.81, sd=0.1), corresponding to moderately to very informative models. Period 2 and rainfall_7 were associated with, respectively, the highest and the lowest absolute values of the estimated coefficients in the glm (Table A2). Air temperature and rainfall in July were associated with positive coefficients, in contrast to wind intensity and to the less eutrophic period (period 2: from 1993 to 2018). The odds ratio associated with the period corresponding to the eutrophication status is 0.17 $\left(e^{-1.78}\right)$, meaning that the fact of being in period 2 divided the risk of triggering anoxia by $5.9(1 / 0.17)$ compared to the risk in period 1 . The odds ratio of the summer monthly average wind intensity was $0.27\left(\mathrm{e}^{-1.32}\right)$, meaning that an increase of 1 unit of wind intensity (the variable wind_ST being standardised) divided the risk by 3.7. The odds ratio associated with air temperature $\left(e^{1.03}=2.8\right)$ means 
that an $1^{\circ} \mathrm{C}$ increase multiplies the risk of triggering anoxia by by 2.8 . Finally, the odds ratio of rainfall in July indicates that a $10 \mathrm{~mm}$ increase multiplies the risk by $1.5\left(\mathrm{e}^{10^{*} 0.04}=1.5\right)$. Figure 8 shows the predicted probabilities of triggering anoxia according to the three significant meteorological variables of the glm for period 1 and period 2, showing that the highest probabilities of the highest temperature were reached in period 1.

\section{Discussion}

\subsection{Ecological changes and regime shifts during oligotrophication}

Our results, based on long time series, show that the pelagic and benthic communities in Thau lagoon changed during the course of oligotrophication. Previous studies of the lagoon from the 1990s to the 2000s showed that the gradual decrease in nutrient inputs from the watershed resulted in a continuous decrease in nutrients and Chl a concentrations in the water column (Collos et al., 2009; Derolez et al. 2020; Deslous-Paoli et al., 1998; Gowen et al., 2015). Our study revealed the continuation of oligotrophication over the past 20 years (1999-2018), and the recovery of the ecosystem, through nutrient and phytoplankton parameters. Thus, based on changes in the summer concentration of DIP in the water, which is a good indicator of the eutrophication status of Thau lagoon (La Jeunesse and Elliott, 2004; Souchu et al., 1998), we identified a progressive shift from a bad quality status to a high quality status, according to the thresholds of the WFD (METS, 2018). Reaching the good DIP status (DIP < $1 \mu$ M, METS, 2018), which was no longer exceeded after June 1993, divided the time series into two periods (1:1970-1992 and 2:1993-2018). At the same time, dissolved nitrogen concentrations also decreased significantly $\left(\mathrm{NO}_{3}{ }^{-}+\mathrm{NO}_{2}{ }^{-}\right.$in June: $\mathrm{MK} p<0.01$, slope $=-0.01 \mu \mathrm{M}$ $\left.y^{-1}\right)$. In period 2, when nutrient levels were already low, phytoplankton shifted with a time lag in year 2006. After 2006, the levels of $\mathrm{Chl}$ a biomass $\left(<5 \mu \mathrm{g} \mathrm{L}^{-1}\right)$ and picoeukaryote abundances $\left(<5010^{6}\right.$ cells $\mathrm{L}^{-1}$ ) corresponded to those reported in oligotrophic coastal waters of the Mediterranean (Massana 2011). Coastal lagoons often host blooms of picophytoplankton that can continue for months to years (Glibert et al 2010; Bec et al. 2011). In Thau lagoon, phycoerythrin-rich picocyanobacteria abundances did not increase significantly but their relative contribution (PE-CYAN/PEUK ratio) to picophytoplankton did.The numerical dominance of picocyanobacteria in summer may reflect the oligotrophic conditions of the lagoon linked to low phosphorus levels (Collos et al., 2009; Bec et al. 2011). We also found a positive correlation between temperature and the abundance of phycoerythrinrich picocyanobacteria. Positive effects of temperature on the growth rate and abundance of 
picocyanobacteria have previously been demonstrated in Thau lagoon (Bec et al. 2005, 2011). These results confirmed the trends expected in coastal ecosystems under oligotrophication and global warming (Glibert, 2016; Pulina et al., 2018; Trombetta et al., 2019). This shift period observed in picophytoplankton in 2006 mirrors the shift in the microphytoplankton community identified in a previous study (decrease in diatom abundance and shift dominance from Skeletonema-Chaetoceros to Chaetoceros-Pseudo-nitzschia in the community between 2005 and 2008) (Derolez et al. 2020). Our results showed a rapid and significant response of the pelagic compartment to the decrease in nutrient loadings comparable to the responses observed in other coastal ecosystems (Boynton et al., 2013; Derolez et al., 2019; Leruste et al., 2016; Lie et al., 2011; Ní Longphuirt et al., 2016) and in lakes (Anneville et al., 2005; Jeppesen et al., 2007).

Decreases in nutrient concentrations and phytoplankton biomass and abundances were associated with a decrease in dissolved oxygen concentrations in summer from 1999 to 2018 . This decrease could be induced by warming which is known to reduce the solubility of oxygen in water and to enhance microbial activity (Breitburg et al., 2018; Conley, 2000; Jager et al., 2018). Moreover, the respiration of shellfish coupled to the decrease in phytoplankton biomass could impact oxygen concentrations in water. Oligotrophication has also been shown to induce changes in trophic functioning, shifting from autotrophic regime to mixotrophic and heterotrophic regimes (Collos et al., 2009; Gowen et al., 2015; Lagarde et al., 2018b), and thus leading to changes in oxygen balance.

Our results provide for the first time a long-term analysis of the benthic compartment of the Thau lagoon. In the sediments, total nitrogen concentrations increased significantly from the 1980 s to the 2010s, suggesting that the benthic compartment stored these nutrients during the eutrophication period. In contrast, we found no significant trend in total phosphorus, whose maximum value was reached in 2003 and whose minimum value was reached in 2014. Such contrasted evolution has already been reported in coastal ecosystems, where the presence of sulphate reduces the efficiency retention of DIP by the sediments and favours recycling of DIP over that of DIN (Caraco et al., 1990; Conley, 2000; Lehtoranta et al., 2009). Moreover, high temperatures and anoxic conditions have a significant effect on benthic fluxes of $\mathrm{NH}_{4}{ }^{+}$and DIP (Souchu et al. 1998; Zilius et al. 2015). In Thau lagoon, we hypothesise that releases from the sediments, coupled with the decrease in inputs from the watershed - corresponding to internal and external nutrient loadings, respectively, (Chapelle et al., 
$2000 \mathrm{~b}$ ) - led to stabilisation, or even to the beginning of a decrease in the quantities of phosphorus in the sediments (lowest median of TP was observed in 2014).

Concerning the benthic macrophyte community, our results showed that the proportion of seagrass decreased in favour of red algae from the 1960s to the 1990s. This trend corresponds to the generic eutrophication trajectory described by many authors: a shift from dominance of seagrass and perennial macrophytes to dominance of macroalgae (Schramm, 1999; Viaroli et al., 2008; Zaldívar et al., 2008). Seagrass meadows only started to slightly recover between 2003 and 2008, but their contribution to benthic vegetation did not reach the level observed in the 1960s, or the historical conditions describing Thau lagoon dominated by seagrass at the beginning of the $20^{\text {th }}$ century (Calvet, 1910). Despite the significant and continuous decrease in nutrient inputs observed since the 1970s, the beginning of the recovery of the Thau lagoon macrophyte community lagged behind that of the phytoplankton community. This time lag and partial recovery suggest hysteresis during oligotrophication in the Thau lagoon and correspond to partial resilience observed in aquatic ecosystems (Borja et al., 2010; Duarte et al., 2009; Elliott et al., 2007). Continuous nutrient fluxes from sediments could promote phytoplankton or macroalgae growth and delay the recovery process of perennial macroalgae and seagrasses (Kosten et al. 2011). Accordingly, internal phosphorus loading from sediments has frequently been reported as a cause of hysteresis in lakes (Gulati and Van Donk, 2002; Jeppesen et al., 2007; Søndergaard et al., 2003) and more recently in coastal or estuarine ecosystems (Lillebø et al., 2007; Ní Longphuirt et al., 2016; Ratmaya et al., 2018; Riemann et al., 2016).

During five decades of changes from eutrophication to oligotrophication, contrasting periods in the pelagic and benthic compartments of the Thau lagoon were identified. This evolution is represented in the conceptual model (Figure 9), showing the changes in several indicators of ecosystem status (DIP concentration in water, phytoplankton and macrophyte) in response to changes in the levels of pressures which affect the ecosystem (nutrient loads and temperature). Although the decrease in nutrient loads was accompanied by a decrease in nutrient concentrations and phytoplankton biomass in water, period 1 (1970-1992) can be considered as a eutrophic period due to the shift from seagrass to red macroalgae and to the frequent and critical anoxic crises during that period. Period 2 (19932018) was characterised by a better eutrophic status, less frequent and less intense anoxia crises and by the continuation of the recovery process. This second period can be divided into three steps: 2a) a 
transition phase (1993-2003) during which the pelagic compartment continued to recover from eutrophication with stabilisation of the benthic community; $2 b$ ) a regime shift between the year 2003 , (before which seagrass continued to decline), and the year 2006, after which low chlorophyll a values were reached in the water column. Since the summers of 2003 and 2006 were both characterised by major heat waves and anoxias events, we hypothesise that this regime shift is the result of the combination of an internal oligotrophication process and external forces linked to high summer temperatures (Sheffer and Carpenter, 2003). After the regime shift, 2c) the ecosystem shifted to oligotrophy (2006-2018), the water column became characteristic of an oligotrophic state and the marine grass began to recover.

\subsection{Triggers of anoxia, resistance and resilience of the ecosystem}

To analyse the trajectory of Thau lagoon ecosystem over five decades, the effects of reduced nutrient inputs and of climatic-related variables, especially the gradual increase in temperature, which was evidenced in the Mediterranean and Thau regions (Bec et al., 2018; Cramer et al., 2018), need to be taken into account. Indeed, oligotrophication and warming may have combined effects on biodiversity and ecosystem functioning (Glibert, 2016; Kosten et al. 2011; Verbeek et al., 2018). Thus, we focused particularly on the occurrence and intensity of anoxia crises as indicators of ecosystem resilience and resistance and on what triggers these disturbances (Coffin et al., 2018).

The model used to predict the triggering of summer anoxia revealed that four variables were significant (three meteorological variables and one corresponding to the eutrophication status). The strongest effect was induced by air temperature, followed by the effect of the eutrophication period, by the negative effect of wind, and to a lesser extent by the positive effect of rainfall in July. These results highlight the effects of climate variables and confirmed a previous study underlying the effects of increasing temperature and decreasing winds on the probability of the occurrence of anoxia in the Thau lagoon (Harzallah and Chapelle, 2002). In coastal ecosystems, decreased wind speed could play an important role in triggering anoxia by decreasing vertical water mixing and oxygenation at the air-water interface (Chen et al., 2015; Du et al., 2018; Zilius et al., 2015). In northern temperate estuaries, increased frequency of extreme summer rainfall events could increase the frequency of anoxia events because floods can mobilize significant quantities of organic matter and suspended solids which are subsequently deposited in estuaries and/or due to more intense stratification (Iriarte et al., 2014; Oviatt et al., 2017). 
We showed a 6-fold higher risk of triggering anoxia in the first period (1970-1992), considered to be the eutrophic period. It is known that anthropogenic nutrient inputs affect both the oxygen supply and uptake (Conley, 2000; Friedrich et al., 2014; Souchu et al., 1998) and that eutrophication-related parameters (chlorophyll a biomass or nutrient concentrations or loadings) can trigger anoxia in coastal areas (Coffin et al. 2018; Du et al. 2018; Zilius et al., 2015). What is remarkable about our result is the marked effect of the eutrophication status, so that the oligotrophication process observed during our study period led to increasing resistance of the Thau lagoon ecosystem to climate stress. Among the climatic-related variables, the effect of air temperature on triggering anoxia was the strongest. Indeed, the functioning of the lagoon could be particularly threatened by warming since increases in the annual average temperature and in the frequency of summer heat waves were recorded in the Mediterranean region from the 1970s to the 2010s (Bec et al., 2018; Cramer et al., 2018). However, oligotrophication lead to the decreased risk of triggering anoxia in the Thau lagoon. This is consistent with a previous study in the mid-estuarine waters (Bilbao, Spain) showing that anthropogenicmediated pollution mitigation was more important than climatic factors in driving inter-annual variations in dissolved oxygen saturation (Iriarte et al., 2014). In Narragansett Bay (USA), Oviatt et al. (2017) showed that a $60 \%$ reduction in nutrient concentrations resulted in a $34 \%$ reduction in summer hypoxia. In Chesapeake Bay (USA), authors suggested that reductions in nutrient loads would also reduce hypoxic volumes (Testa et al., 2014), but biological conditions (linked to nutrient loading) and physical conditions (vertical exchange and temperature) could play an equally important role in seasonal and inter-annual variations in the hypoxic condition of this ecosystem (Du et al., 2018). Among the climatic-related variables, we also showed a decrease in the rainfall levels from period 1 to period 2, due to the decrease in the occurrence of wet years recorded since 2005 (Bec et al., 2018). This trend may have facilitated the oligotrophication process by decreasing nutrient inputs resulting from watershed runoff (Bec et al., 2018).

With climate change trends already demonstrated by regional meteorological experts and predicted for the future (Jouzel et al., 2014), we would expect the effects of climate warming to slow down or even reverse the recovery process observed in the Thau lagoon. At regional scale, meteorological datas revealed that 2003, 2017 and 2018 were the three hottest summers in the 1970-2018 period (MétéoFrance, 2018). In the present study, the last anoxia crisis occurred in 2018 when the water column was characteristic of an oligotrophic state (Figure 9) and after a 12-years period without anoxic event. 
This support the conclusions drawn in the Mediterranean Basin where accelerated climate change could exacerbate existing environmental problems (Cramer et al 2018). Similar results have been reported these limits in Lake Zurich, where, despite the success achieved in fighting eutrophication, a recent increase in hypoxia has been observed (Friedrich et al., 2014). In Chesapeake Bay, it has been shown that the expected climate changes will exacerbate physical conditions, which would also amplify the negative impact of human-induced eutrophication, requiring greater efforts to reduce nutrient inputs in order to reach a satisfactory level of water quality (Du et al., 2018). Finally, a recent study (Jager et al., 2018) reviewed ways to enhance the resilience of coastal aquatic ecosystems in the face of future, unnatural hypoxic regimes. In addition to efforts to slow climate change, the measures identified by these authors include: reducing nutrient and carbon loadings from rivers, restoring aquatic vegetation, increasing oxygen exchange in sediments and water clarity via the management of key species such as seagrass, or the protection of oyster and mussel beds (Jager et al., 2018). The restoration of the health of oyster reefs and the expansion of tidal marshes were also shown to reinforce the improvement of water and habitat quality along a restoration trajectory in Chesapeake Bay (Kemp et al., 2005). The choice of management options first requires the definition of a desirable state for the ecosystem. Jager et al. (2018) defined desired states as ecosystems with long trophic chains and slow nutrient and carbon dynamics that provide many ecosystem services. Other authors have shown that different levels of Mediterranean coastal lagoon restoration may be desired by society in terms of recovery of ecosystems, and that some discrepancies can be observed between social representations and ecological diagnoses (Audouit et al., 2017; de Wit et al., 2015).

\subsection{Management of restoration and shellfish farming}

In Thau lagoon, the significant efforts invested by public stakeholders and managers to mitigate eutrophication which began in the 1970s have succeeded in reducing the occurrence of anoxia events by increasing ecosystem resistance and achieved the good water column status targeted by the WFD. Official assessments of the biological quality elements in application of the WFD have only been carried out since 2009 in Thau lagoon. According to these diagnoses, the phytoplankton has reached the good status in 2009 and shifted to a high status in 2018 (Andral and Sargian, 2010; Bouchoucha et al., 2019). However, the macrophytes remained in a medium status from 2009 to 2018, although an improvement was observed, associated with the increase in the coverage of Zostera spp. The delay in reaching the WFD good status for macrophytes in comparison to phytoplankton is related to the time 
lag evidenced by several authors in the recovery of the benthic compartment (Borja et al., 2010; Le Fur et al., 2019). A recent study carried out on several French Mediterranean lagoons (Derolez et al., 2019) hypothesised that the level of recovery after the reduction of nutrient inputs could be affected by: (i) external drivers, such as completeness of nutrient reduction, marine connectivity, or climate change; (ii) internal factors such as physical traits, sediment nutrient stocks or the presence of residual seagrass patches or seed stocks; and interactions between the two drivers. Among the three strategies identified for the lagoons which have not fully achieved the objectives set by the European WFD ("Wait and see", "Go further", "Give a helping hand"), the first seems to be the most relevant for the Thau lagoon according to the importance of the works performed on the depuration system and their efficiency observed in the ecosystem. One could hypothesise that eutrophication pressure is now sufficiently low to allow the benthic compartment to recover its ecological functions and structure of the reference conditions, after a period of hysteresis.

However, it should be noted that in the 1990s, some authors mentioned the threat of reaching the limits of the trophic capacity of the Thau lagoon if the depuration works became too drastic (DeslousPaoli et al., 1998; Souchu et al., 1998). During the recovery, shellfish production in Thau lagoon has evolved due to changes in the main reared species from mussels to oysters from the 1970 s to the 1990s for epizootic and economic reasons (Hamon and Tournier, 1984; Le Brun, 1985); the removal of some shellfish structures located along the shoreline in the early 2000s following the recommendations of scientists made after the critical anoxia events of the 1990s (Deslous-Paoli et al., 1998; Souchu et al., 2011); and changes in farming techniques following epizootics such as OsHV-1 in 2008 (Pernet et al., 2014). This last epizootic reduced oyster production by half. More recently, fishermen and shellfish farmers have been facing economic difficulties and they worry about the potential limiting capacity of the ecosystem (Derolez et al. 2020). In the context of emerging marine diseases related to climate change, recent studies have shown that the impact of oyster diseases can be limited by maintaining the good ecological status of coastal waters (Harvell et al., 1999; Pernet et al., 2018). To reach a satisfactory trade-off between uses, ecosystem services and maintaining biodiversity and ecological functions under global change, there is a need to use ecosystem-based models (Filgueira et al. 2015; Guyondet et al., 2014; McKindsey et al., 2006). Such a model has been developed for Thau lagoon and showed that lagoon productivity significantly depends on hydrometerology, with higher oyster production in wet years than in dry years (Pete et al., 2020). 
Using a modeling approach based on scenario comparisons would help (i) disentangle the effects of anthropogenic forcings and of climate driven variables such as increasing temperature or decreasing rainfall and (ii) determine the limits of ecological tolerance. By testing different management and climate scenarios, this modelling approach would also help decision-makers better target their actions to improve the ecosystem's resistance to increasing climate pressure. It is will also be necessary to increase high-frequency oxygen measurements in real time (Friedrich et al., 2014; Schmidt et al., 2017) to help managers and shellfish farmers better anticipate the appearance of hypoxia/anoxia and design and apply mitigation actions (e.g. emersion of oysters at night) to mitigate environmental and economic impacts. Finally, in the context of global change, Breitburg et al. (2018) recommend an integrated framework, combining modelling, observations and experiments and involving all stakeholders (scientists, local governments, shellfish farmers) to facilitate the development and implementation of the most ecologically and economically effective management strategy to reduce anoxia.

\section{Conclusions}

The processes and consequences of oligotrophication have been poorly studied in coastal lagoons from a long-term perspective and at ecosystem scale. By analysing time series over 5 decades of observations on pelagic and benthic autotrophic communities, our study shows how the decrease in nutrient inputs led to major ecological changes in a Mediterranean coastal lagoon used for shellfish farming. Considering anoxia crises as indicators of ecosystem resilience and resistance, the combined analysis of meteorological data, eutrophication status and shellfish production over these 5 decades allowed us to identify air temperature and eutrophication status as the two main triggers of summer anoxia.

We identified successive periods in ecosystem functioning during the oligotrophication process: a eutrophic period characterised by a shift from dominance by seagrass to dominance by red macroalgae; a 3-step period characterised by a better eutrophication status i.e. a transition phase with a stable benthic community, a regime shift between two heat waves and anoxic crises; and finally the achievement of oligotrophic conditions. Our analyses also show that oligotrophication has led to changes in the drivers of summer anoxia, making the ecosystem more resistant to climatic stress caused by high summer temperatures. 
However, with predicted climate change trends, we would expect the effects of climate warming to slow down or even to reverse the observed recovery process. The development and use of ecosystem-based models are now needed to better understand the functioning of the ecosystem and to help stakeholders find a trade-off between uses, ecosystem services and the maintenance of biodiversity and ecological functions in the context of global change. 


\section{Funding}

This study was based on data collected during the projects "Réseau de Suivi Lagunaire" and Water Framework Directive, which received financial support from Ifremer, Agence de l'Eau Rhône Méditerranée Corse, Région Languedoc-Roussillon/Occitanie et Cépralmar. Historical data on macrophytes and sediment were collected during a project funded by the French Government, Herault Department and Region Languedoc-Roussillon (Lauret, 1990 \& 1994), by PIREN, Ifremer and the French Ministry of Environnement (ECOTHAU) (Gerbal and Verlaque, 1995; Péna and Picot, 1991) and by PNEC "Lagunes Méditerranéennes" (Verlaque, 2000).

\section{Acknowledgements}

This article is dedicated to the memory of Jocelyne Oheix.

The authors are extremely grateful to Grégory Messiaen, Elodie Foucault, Dominique Munaron, Martine Fortuné and Elise Hatey for nutrient and phytoplankton analyses and to Nicolas Cimiterra for producing the maps. We thank our colleagues at Ifremer LERLR for their help during field investigations. The authors would like to thank CIRAD for sediment analyses; Ms Dubuisson, Ms Guyon and Mr Soubeyroux of DCSC Météo-France for meteorological data and expertise; Ludovic Cesmat (SMBT) for information on watershed inputs; DDTM/DML for data on shellfish production. We are particularly grateful to Michel Lauret, Jean-Louis Guillou, Thierry Laugier, Philippe Souchu, Marianela Pataccini-Alvarez, Anahita Marzin, Laury Dijoux and Hugo Daurin for their help with data collection and pre-processing; and to Dominique Soudant, Meïli Baragatti, Tarek Hattab and Grégoire Certain and Sandeep Kumar Patakamuri for their help with statistics.

\section{References}

Aminot, A., Kérouel, R., 2007. Dosage automatique des nutriments dans les eaux marines, Quae ed. Versailles. 188 pp.

Anneville, O., Gammeter, S., Straile, D., 2005. Phosphorus decrease and climate variability: mediators of synchrony in phytoplankton changes among European perialpine lakes. Freshw. Biol. 50, 1747-1771. doi:10.1111/ j.1365-2427.2005.01429.x

Audouit, C., Pasqualini, V., Wit, R. De, Flanquart, H., Deboudt, P., Ru, C., 2017. Comparing social representation of water quality in coastal lagoons with normative use of ecological indicators. 
Mar. Policy. doi:10.1016/J.MARPOL.2017.08.023

Bec, B., Collos, Y., Souchu, P., Vaquer, A., Lautier, J., Fiandrino, A., Benau, L., Orsoni, V., Laugier, T., 2011. Distribution of picophytoplankton and nanophytoplankton along an anthropogenic eutrophication gradient in French Mediterranean coastal lagoons. Aquat. Microb. Ecol. 63, 29-45. doi:10.3354/ame01480

Bec, B., Husseini-Ratrema, J., Collos, Y., Souchu, P., Vaquer, A., 2005. Phytoplankton seasonal dynamics in a Mediterranean coastal lagoon: Emphasis on the picoeukaryote community. J. Plankton Res. 27, 881-894. doi:10.1093/plankt/fbi061

Bec, B., Derolez V., Cesmat, L., Pete, R., Richard, M. 2018. Projet CAPATHAU : CAPAcité trophique de la lagune de THAU. Livrable 1. Evolution temporelle de l'état écologique de la lagune de Thau et des performances des coquillages en élevage au regard de la réduction des apports issus du bassin versant et des changements météorologiques. Rapport UMR MARBEC DLAL FEAMP. Report in French. 157 pp.

Borja, A., Dauer, D.M., Elliott, M., Simenstad, C.A., 2010. Medium-and Long-term Recovery of Estuarine and Coastal Ecosystems: Patterns, Rates and Restoration Effectiveness. Estuaries and Coasts 33, 1249-1260. doi:10.1007/s12237-010-9347-5

Bouchoucha, M., Derolez, V., Munaron, M., Cimiterra, N., Tomasino, C. 2019. Directive Cadre sur l'Eau. Bassin Rhône Méditerranée Corse - Année 2018. Report in French. 81 p.

Boynton, W.R., Hodgkins, C.L.S., O'Leary, C.A., Bailey, E.M., Bayard, A.R., Wainger, L.A., 2013. Multi-decade Responses of a Tidal Creek System to Nutrient Load Reductions: Mattawoman Creek, Maryland USA. Estuaries and Coasts 37, 111-127. doi:10.1007/s12237-013-9690-4

Breitburg, D., Levin, L.A., Oschlies, A., Grégoire, M., Chavez, F.P., Conley, D.J., Garçon, V., Gilbert, D., Gutiérrez, D., Isensee, K., Jacinto, G.S., Limburg, K.E., Montes, I., Naqvi, S.W.A., Pitcher, G.C., Rabalais, N.N., Roman, M.R., Rose, K.A., Seibel, B.A., Telszewski, M., Yasuhara, M., Zhang, J., 2018. Declining oxygen in the global ocean and coastal waters. Science 359 (6371). doi:10.1126/science.aam7240

Calinski ,T., Harabasz, J., 1974. A dendrite method for cluster analysis. Communications in Statistics, 3(1): 1-27. 
Calvet, L., 1910. L'ostréiculture à Cette et dans la région de l'étang de Thau. Bull. la Société Cent. d'Aquaculture Pêche. 1-107.

Caraco, N., Cole, J., Likens, G.E., 1990. A comparison of phosphorus immobilization in sediments of freshwater and coastal marine systems. Biogeochemistry 9, 277-290. doi:10.1007/BF00000602

Chapelle, A., Lazure, P., Souchu, P., 2000a. Modelling anoxia in the Thau lagoon (France). Oceanol. Acta 24, S87-S97. doi : 10.1016/S0304-3800(99)00206-9

Chapelle, A., Ménesguen, A., Deslous-paoli, J., Souchu, P., 2000b. Modelling nitrogen, primary production and oxygen in a Mediterranean lagoon. Impact of oysters farming and inputs from the watershed. Ecol. Modell. 127, 161-181.

Chen, X., Shen, Z., Li, Y., Yang, Y., 2015. Physical controls of hypoxia in waters adjacent to the Yangtze Estuary: A numerical modeling study. Mar. Pollut. Bull. 97, 349-364. doi:10.1016/j.marpolbul.2015.05.067

Coffin, M.R.S., Courtenay, S.C., Pater, C.C., van den Heuvel, M.R., 2018. An empirical model using dissolved oxygen as an indicator for eutrophication at a regional scale. Mar. Pollut. Bull. 133, 261-270. doi:10.1016/j.marpolbul.2018.05.041

Collos, Y., Bec, B., Jauzein, C., Abadie, E., Laugier, T., Lautier, J., Pastoureaud, A., Souchu, P., Vaquer, A., 2009. Oligotrophication and emergence of picocyanobacteria and a toxic dinoflagellate in Thau lagoon, southern France. J. Sea Res. 61, 68-75. doi:10.1016/j.seares.2008.05.008

Comps, M.A., 2000. La qualité bactériologique des coquillages de l'étang de Thau. Analyse des données de colimétrie recueillies entre 1971 et 1998. Relations avec l'état de l'assainissement des communes du bassin versant. 73 p. https://archimer.ifremer.fr/doc/00039/15012/

Conley, D.J., 2000. Biogeochemical nutrient cycles and nutrient management strategies. Hydrobiologia 410, 87-96. doi:10.1023/A:1003784504005

Cramer, W., Guiot, J., Fader, M., Garrabou, J., Gattuso, J.-P., Iglesias, A., Lange, M.A., Lionello, P., Llasat, M.C., Paz, S., Peñuelas, J., Snoussi, M., Toreti, A., Tsimplis, M.N., Xoplaki, E., 2018. Climate change and interconnected risks to sustainable development in the Mediterranean. Nat. Clim. Chang. 8. doi:10.1038/ s41558-018-0299-2 
de Jonge, V.N., Elliott, M., 2001. Eutrophication. Encycl. Ocean Sci. 2, 852-870

De Wit, R., Leruste, A., Le Fur, I., Sy, M.M., Bec, B., Ouisse, V., Derolez, V., Rey-Valette, H., 2020. A multidisciplinary approach for restoration ecology of shallow coastal lagoons, a case study in South France. Front. Ecol. Evol. - Conserv. doi:10.3389/fevo.2020.00108

de Wit, R., Rey-Valette, H., Balavoine, J., Ouisse, V., Lifran, R., 2015. Restoration ecology of coastal lagoons: new methods for the prediction of ecological trajectories and economic valuation. Aquat. Conserv. Mar. Freshw. Ecosyst. 27, 137-157. doi:10.1002/aqc.2601

DeLong, E.R., DeLong, D.M., Clarke-Pearson, D.L., 1988. Comparing areas under two or more correlated Receiver Operating Characteristic curves: a nonparametric approach. Biometrics, 44(3):837-845. http://dx.doi.org/10.2307/2531595

Derolez, V., Oheix, J., Ouisse, V., Munaron, D., Fiandrino, A., Messiaen, G., Hubert, C., Lamoureux, A., Malet, N., Fortuné, M., Berard, L., Mortreux, S., Guillou, J.L. 2015. Suivi estival des lagunes méditerranéennes françaises. Bilan des résultats 2014. 86 pp. Report in French. https://archimer.ifremer.fr/doc/00273/38461/

Derolez, V., Bec, B., Munaron, D., Fiandrino, A., Pete, R., Simier, M., Souchu, P., Laugier, T., Aliaume, C., Malet, N., 2019. Recovery trajectories following the reduction of urban nutrient inputs along the eutrophication gradient in French Mediterranean lagoons. Ocean Coast. Manag. 171, 1-10. doi:10.1016/j.ocecoaman.2019.01.012

Derolez, V., Soudant, D., Malet, N., Chiantella, C., Richard, M., Abadie, E., Aliaume, C., Bec, B. (2020). Two decades of oligotrophication: evidence for a phytoplankton community shift in the coastal lagoon of Thau (Mediterranean Sea, France). Estuar. Coast. Shelf Sci. In press.

Deslous-Paoli, J.-M., Souchu, P., Mazouni, N., Juge, C., Dagault, F., 1998. Relations milieuressources: impact de la conchyliculture sur un environnement lagunaire méditerranéen (Thau). Oceanol. Acta 21, 831-843. doi:10.1016/S0399-1784(99)80010-3

Du, J., Shen, J., Park, K., Wang, Y.P., Yu, X., 2018. Worsened physical condition due to climate change contributes to the increasing hypoxia in Chesapeake Bay. Sci. Total Environ. 630, 707717. doi:10.1016/j.scitotenv.2018.02.265

Duarte, C.M., Conley, D.J., Carstensen, J., Sánchez-Camacho, M., 2009. Return to Neverland: 
Shifting baselines affect eutrophication restoration targets. Estuaries and Coasts 32, 29-36. doi:10.1007/s12237-008-9111-2

Dubois, A., 1972. Le peuplement végétal du bassin de Thau. Rapp. Comm. Int. Mer Médit. 20, 495497.

EC. 2000, Directive 200/60/EC of the European parliament and of the council of 23 October 2000 establishing a framework for community action in the field of water policy.

EC. 1991a, Council Directive 91/271/EEC concerning urban waste-water treatment.

EC. 1991b, Council Directive 91/676/EEC of 12 December 1991 concerning the protection of waters against pollution caused by nitrates from agricultural sources.

Elliott, M., Burdon, D., Hemingway, K.L., Apitz, S.E., 2007. Estuarine, coastal and marine ecosystem restoration: Confusing management and science - A revision of concepts. Estuar. Coast. Shelf Sci. 74, 349-366. doi:10.1016/j.ecss.2007.05.034

Elliott, M., Quintino, V., 2007. The Estuarine Quality Paradox, Environmental Homeostasis and the difficulty of detecting anthropogenic stress in naturally stressed areas. Mar. Pollut. Bull. 54, 640645. doi:10.1016/j.marpolbul.2007.02.003

Fiandrino, A., Ouisse, V., Dumas, F., Lagarde, F., Pete, R., Malet, N., Le Noc, S., de Wit, R., 2017. Spatial patterns in coastal lagoons related to the hydrodynamics of seawater intrusion. Mar. Pollut. Bull. 119, 132-144. doi:10.1016/j.marpolbul.2017.03.006

Filgueira, R., Comeau, L.A., Guyondet, T., McKindsey, C.W., Byron, C.J. 2015. Modelling Carrying Capacity of Bivalve Aquaculture: A Review of Definitions and Methods. In Encyclopedia of Sustainability Science and Technology, Springer S, 1-33. New York. doi:10.1007/978-1-49392493-6_945-1

Friedrich, J., Janssen, F., Aleynik, D., Bange, H.W., Boltacheva, N., Çagatay, M.N., Dale, A. W., Etiope, G., Erdem, Z., Geraga, M., Gilli, A., Gomoiu, M.T., Hall, P.O.J., Hansson, D., He, Y., Holtappels, M., Kirf, M.K., Kononets, M., Konovalov, S., Lichtschlag, A., Livingstone, D.M., Marinaro, G., Mazlumyan, S., Naeher, S., North, R.P., Papatheodorou, G., Pfannkuche, O., Prien, R., Rehder, G., Schubert, C.J., Soltwedel, T., Sommer, S., Stahl, H., Stanev, E. V., Teaca, A., Tengberg, A., Waldmann, C., Wehrli, B., Wenzhöfer, F. 2014. Investigating hypoxia in aquatic 
environments: Diverse approaches to addressing a complex phenomenon. Biogeosciences 11, 1215-1259. doi:10.5194/bg-11-1215-2014

Gangnery, A., 1998. Estimation des stocks de bivalves en élevage et des épibiontes dans la lagune de Thau en 1998. Evolution depuis 1980. Palavas Les Flots: Rapport ENSAR//fremer. 55 pp. Report in French.

Gangnery, A., 1999. Estimation des stocks de bivalves en élevage et des épibiontes dans la lagune de Thau et Modélisation de la dynamique des populations d'huitres creuses (Crassostrea gigas, Thunberg). Rapport de DEA. Palavas Les Flots: Université Paris VI//fremer/CREMA. 38 pp. Report in French. https://archimer.ifremer.fr/doc/00443/55478/

Gangnery, A., Bacher, C., Buestel, D., 2001. Assessing the production and the impact of cultivated oysters in the Thau lagoon (Mediterranee, France) with a population dynamics model. Can. J. Fish. Aquat. Sci. 58, 1012-1020. doi:10.1139/cjfas-58-5-1012

Gangnery, A., Chabirand, J.M., Lagarde, F., Le Gall, P., Oheix, J., Bacher, C., Buestel, D., 2003. Growth model of the Pacific oyster, Crassostrea gigas, cultured in Thau Lagoon (Méditerranée, France). Aquaculture 215, 267-290. doi:10.1016/S0044-8486(02)00351-4

Gangnery, A., 2003. Etude et modélisation de la dynamique des populations de bivalves en élevage (Crassostrea gigas et Mytilus galloprovincialis) dans le bassin de Thau (Méditerranée, France) et des ascidies solitaires associées. PhD thesis, Montpellier University, 216 pp.

Gerbal, M., Verlaque, M., 1995. Macrophytobenthos de substrat meuble de l'étang de Thau. Oceanol. Acta $18,557-571$

Gladstone-Gallagher, R. V., Pilditch, C.A., Stephenson, F., Thrush, S.F., 2019. Linking traits across ecological scales determines functional resilience. Trends Ecol. Evol. 1-11. doi:10.1016/j.tree.2019.07.010

Glibert, P.M, Boyer, J.N., Heil, C.A., Madden, C., Sturgis, B., Wazniak, C.S. 2010. Blooms in lagoons: different from those of river-dominated estuaries. In: Kennish M., Paerl H. (Eds.) Coastal lagoons: critical habitats of environmental change. CRC Press, Boca Raton, FL.

Glibert, P.M., 2016. Margalef revisited: A new phytoplankton mandala incorporating twelve dimensions, including nutritional physiology. Harmful Algae 55, 25-30. 
doi:10.1016/j.hal.2016.01.008

Gowen, R.J., Collos, Y., Tett, P., Scherer, C., Bec, B., Abadie, E., Allen, M., O'Brien, T., 2015. Response of diatom and dinoflagellate lifeforms to reduced phosphorus loading: A case study in the Thau lagoon, France. Estuar. Coast. Shelf Sci. 162, 45-52. doi:10.1016/j.ecss.2015.03.033

Grizel, H., Héral, M., 1991. Introduction into France of the Japanese oyster (Crassostrea gigas), Journal du Conseil International pour l'Exploration de la Mer 47, 399-403. http://archimer.ifremer.fr/doc/00000/2760/

Gulati, R.D., Van Donk, E., 2002. Lakes in the Netherlands, their origin, eutrophication and restoration: State-of-the-art review. Hydrobiologia 478, 73-106.

Guyondet, T., Comeau, L. a., Bacher, C., Grant, J., Rosland, R., Sonier, R., Filgueira, R., 2014. Climate Change Influences Carrying Capacity in a Coastal Embayment Dedicated to Shellfish Aquaculture. Estuaries and Coasts 38, 1593-1618. doi:10.1007/s12237-014-9899-x

Hamed, K.H., Rao, A.R., 1998. A modified Mann-Kendall trend test for autocorrelated data. J. Hydrol. 204, 182-196. doi:10.1016/S0022-1694(97)00125-X

Hamon, P.-Y., Tournier, H., 1984. Evolution de la biomasse de mollusques en élevage dans l'étang de Thau de 1980 à 1984. Rev. Trav. Inst. Pêches marit. 48, 33-44.

Hamon, P.Y., 2000. Les malaïgues de l'étang de Thau. 129 pp. Report in French.

Harvell, C.D., Kim, K., Burkholder, J.M., Colwell, R.R., Epstein, P.R., Grimes, D.J., Hofmann, E.E., Lipp, E.K., Osterhaus, A.D.M.E., Overstreet, R.M., Porter, J.W., Smith, G.W., Vasta, G.R., 1999. Emerging marine diseases - Climate links and anthropogenic factors. Science 285, 1505-1510. doi:10.1126/science.285.5433.1505

Harzallah, A., Chapelle, A., 2002. Contribution of climate variability to occurrences of anoxic crises "malaïgues" in the Thau lagoon (southern France). Oceanol. Acta 25, 79-86. doi:10.1016/S03991784(02)01184-2

Ifremer, CREOCEAN, Université Montpellier II, 2000. Mise à jour d'indicateurs du niveau d'eutrophisation des milieux lagunaires méditerranéens. Tomes 1 et 2. Rapport final. Report in French. $412 \mathrm{pp}$. 
Ifremer, 2004. Réseau de Suivi Lagunaire du Languedoc-Roussillon. Bilan des résultats 2003. 447 pp. Report in French. https://archimer.ifremer.fr/doc/00275/38591/

Ifremer, 2009. Réseau de Suivi Lagunaire du Languedoc-Roussillon. Bilan des résultats 2008. 366 pp. Report in French. https://archimer.ffremer.fr/doc/00118/22922/

Ifremer, 2012. Réseau de Suivi Lagunaire du Languedoc-Roussillon. Bilan des résultats 2011. 292 pp. Report in French. https://archimer.ifremer.fr/doc/00118/22913/

Iriarte, A., Villate, F., Uriarte, I., Alberdi, L., Intxausti, L., 2014. Dissolved Oxygen in a Temperate Estuary: the Influence of Hydro-climatic Factors and Eutrophication at Seasonal and Inter-annual Time Scales. Estuaries and Coasts 38, 1000-1015. doi:10.1007/s12237-014-9870-x

Jager, H.I., Novello, R.C., Dale, V.H., Villnas, A., Rose, K.A., 2018. Unnatural hypoxic regimes. Ecosphere 9, e02408. doi:10.1002/ecs2.2408

Jeppesen, E., Søndergaard, M., Meerhoff, M., Lauridsen, T.L., Jensen, J.P., 2007. Shallow lake restoration by nutrient loading reduction. Some recent findings and challenges ahead. Hydrobiologia 584, 239-252. doi:10.1007/s10750-007-0596-7

Jouzel, J., Ouzeau, G., Déqué, M., Jouini, M., Planton, S., Vautard, R., 2014. Le Climat de la France au XXle siècle. Scénarios régionalisés : édition 2014 pour la métropole et les régions d'outremer, Rapports de la Direction générale de l'Energie et du Climat.

Kamenir, Y., Morabito, G., 2009. Lago Maggiore oligotrophication as seen from the long-term evolution of its phytoplankton taxonomic size structure. J. Limnol. 68, 146-161. doi:10.4081/jlimnol.2009.146

Kemp, W.M., Boynton, W.R., Adolf, J.E., Boesch, D.F., Boicourt, W.C., Brush, G., 2005. Eutrophication of Chesapeake Bay : historical trends and ecological interactions 303, 1-29.

Kermagoret, C., Claudet, J., Derolez, V., Nugues, M.M., Ouisse, V., Quillien, N., Baulaz, Y., Le Mao, P., Scemama, P., Vaschalde, D., Bailly, D., Mongruel, R., 2019. How does eutrophication impact bundles of ecosystem services in multiple coastal habitats using state-and-transition models. Ocean Coast. Manag. 174, 144-153. doi:10.1016/j.ocecoaman.2019.03.028

Kosten, S., Jeppesen, E., Huszar, V.L.M., Mazzeo, N., Van Nes, E.H., Peeters, E.T.H.M., Scheffer, M., 2011. Ambiguous climate impacts on competition between submerged macrophytes and 
phytoplankton in shallow lakes. Freshw. Biol. 56, 1540-1553. doi:10.1111/j.13652427.2011.02593.x

La Jeunesse, I., Cirelli, C., Sellami, H., Aubin, D., Deidda, R., Baghdadi, N., 2015. Is the governance of the Thau coastal lagoon ready to face climate change impacts? Ocean Coast. Manag. 1-13. doi:10.1016/j.ocecoaman.2015.05.014

La Jeunesse, I., Deslous-Paoli, J.M., Ximénès, M.C., Cheylan, J.P., Mende, C., Borrero, C., Scheyer, L., 2002. Changes in point and non-point sources phosphorus loads in the Thau catchment over 25 years (Mediterranean Sea - France). Hydrobiologia 475-476, 403-411. doi:10.1023/A:1020351711877

La Jeunesse, I., Elliott, M., 2004. Anthropogenic regulation of the phosphorus balance in the Thau catchment-coastal lagoon system (Mediterraean Sea, France) over 24 years. Mar. Pollut. Bull. 48, 679-87. doi:10.1016/j.marpolbul.2003.10.011

Lagarde, F., 2018a. Malaïgue sur la lagune de Thau, expertise de la température de l'eau de la lagune de Thau. Expertise for DDTM34/DML Sète (2018/08/13). 2 pp. Report in French.

Lagarde, F., Richard, M., Bec, B., Roques, C., Mortreux, S., Bernard, I., Chiantella, C., Messiaen, G., Nadalini, J.B., Hori, M., Hamaguchi, M., Pouvreau, S., Roque d'Orbcastel, E., Tremblay, R., 2018b. Trophic environments influence size at metamorphosis and recruitment performance of Pacific oysters. Mar. Ecol. Prog. Ser. 602, 135-153. doi:10.3354/meps12666.

Lauret, M., 1970. Morphologie, phénologie, répartition des Polysiphonia marins du littoral languedocien. Nat. Monspel. sér. Bot. 21, 121-163.

Lauret, M., 1967. Morphologie, phénologie, répartition des Polysiphonia marins du littoral languedocien 1. Section Oligosiphonia. Nat. Monspel. sér. Bot. 18, 347-387.

Lauret, M., 1990. Les herbiers de zostères de l'étang de Thau. Campagne 1990 des Onglous à Mèze. 11 pp. Report in French.

Lauret, M., 1994. Les herbiers de zostères de l'étang de Thau. Campagne 1994 de Mèze à la Crique de l'Angle. Bassin des Eaux Blanches. des Onglous à Mèze. 13 pp. + maps. Report in French.

Le Brun, E., 1985. La conchyliculture dans le bassin de Thau: approche des exploitations conchylicoles. Rapport final. Report in French. 
Le Fur, I., de Wit, R., Plus, M., Oheix, J., Derolez, V., Simier, M., Malet, N., Ouisse, V., 2019. Reoligotrophication trajectories of macrophyte assemblages in Mediterranean coastal lagoons studied from 17-years' time-series. Mar. Ecol. Prog. Ser. 608, 13-32. doi:https://doi.org/10.3354/meps12814 MARINE

Le Fur, I., de Wit, R., Plus, M., Oheix, J., Simier, M., Ouisse, V., 2017. Submerged benthic macrophytes in Mediterranean lagoons: distribution patterns in relation to water chemistry and depth. Hydrobiologia 808, 175-200. doi:10.1007/s10750-017-3421-y

Lehtoranta, J., Ekholm, P., Pitkänen, H., 2009. Coastal eutrophication thresholds: A matter of sediment microbial processes. Ambio 38, 303-308. doi:10.1579/09-A-656.1

Leruste, A., Malet, N., Munaron, D., Derolez, V., Hatey, E., Collos, Y., de Wit, R., Bec, B., 2016. First steps of ecological restoration in Mediterranean lagoons: shifts in phytoplankton communities. Estuar. Coast. Shelf Sci. 180, 190-203. doi:10.1016/j.ecss.2016.06.029

Lie, A.A.Y., Wong, C.K., Lam, J.Y.C., Liu, J.H., Yung, Y.K., 2011. Changes in the nutrient ratios and phytoplankton community after declines in nutrient concentrations in a semi-enclosed bay in Hong Kong. Mar. Environ. Res. 71, 178-188. doi:10.1016/j.marenvres.2011.01.001

Lillebø, A.I., Teixeira, H., Pardal, M.A., Marques, J.C., 2007. Applying quality status criteria to a temperate estuary before and after the mitigation measures to reduce eutrophication symptoms. Estuar. Coast. Shelf Sci. 72, 177-187. doi:10.1016/j.ecss.2006.10.012

Massana, R., 2011. Eukaryotic picoplankton in surface oceans. Annu. Rev. Microbiol 65, 91-110. doi: 10.1146/annurev-micro-090110-102903

Mazouni, N., Gaertner, J., Deslous-Paloi, J.-M., 1998. Influence of oyster culture on water column characteristics in a coastal lagoon ( Thau , France ). Hydrobiologia 373/374, 149-156.

Mazouni, N., Gaertner, J.C., Deslous-Paoli, J.M., Landrein, S., Geringer D’Oedenberg, M., 1996. Nutrient and oxygen exchanges at the water-sediment interface in a shellfish farming lagoon (Thau, France). J. Exp. Mar. Bio. Ecol. 205, 91-113. doi:10.1016/S0022-0981(96)02594-4

McKindsey, C.W., Thetmeyer, H., Landry, T., Silvert, W., 2006. Review of recent carrying capacity models for bivalve culture and recommendations for research and management. Aquaculture 261, 451-462. doi:10.1016/j.aquaculture.2006.06.044 
McCullagh, P., Nelder, J.A., 1989. Generalized Linear Models. London: Chapman and Hall. Monographs on statistics and applied probability. $526 \mathrm{p}$.

Météo-France, 2018. Bilan climatique de l'été 2018. http://www.meteofrance.fr/climat-passe-etfutur/bilans-climatiques/bilan-2018/bilan-climatique-de-l-ete-2018

Millet, B., 1989. Fonctionnement hydrodynamique du bassin de Thau. Validation d'un modèle numérique de circulation (programme ECOTHAU). Ocean. Acta 12, 37-46.

Minghelli-Roman, A., Laugier, T., Polidori, L., Mathieu, S., Loubersac, L., Gouton, P., 2011. Satellite survey of seasonal trophic status and occasional anoxic "malaigue" cirses in the Thau lagoon using MERIS images. Int. J. Remote Sens. 32, 909-923.

Mozetič, P., Solidoro, C., Cossarini, G., Socal, G., Precali, R., Francé, J., Bianchi, F., De Vittor, C., Smodlaka, N., Fonda Umani, S., 2010. Recent trends towards oligotrophication of the northern Adriatic: Evidence from chlorophyll a time series. Estuaries and Coasts 33, 362-375. doi:10.1007/s12237-009-9191-7

MTES, 2018. Arrêté du 27 juillet 2018 modifiant l'arrêté du 25 janvier 2010 relatif aux méthodes et critères d'évaluation de l'état écologique, de l'état chimique et du potentiel écologique des eaux de surface pris en application des articles R. 212-10, R. 212-11 et R. 212-18 du code de l'environnement. 76 p. JORF n0199.

https://www.legifrance.gouv.fr/eli/arrete/2018/7/27/TREL1819388A/jo/texte

Neveux, J., Lantoine, F. 1993. Spectrofluorometric assay of chlorophylls and phaeopigments using the least squares approximation technique. Deep-Sea Research Part I - Oceanographic Research papers 40: 1747-1765.

Newton, A., Brito, A.C., Icely, J.D., Derolez, V., Clara, I., Angus, S., Schernewski, G., Inácio, M., Lillebø, A.I., Sousa, A.I., Béjaoui, B., Solidoro, C., Tosic, M., Cañedo-Argüelles, M., Yamamuro, M., Reizopoulou, S., Tseng, H.-C., Donata, C., Roselli, L., Maanan, M., Cristina, S., RuizFernández, A.C., Lima, R., Kjerfve, B., Rubio-Cisneros, N., Pérez-Ruzafa, A., Marcos, C., Pastres, R., Pranovi, F., Snoussi, M., Turpie, J., Tuchkovenko, Y., Dyack, B., Brookes, J., Povilanskas, R., Khokhlov, V., 2018. Assessing, quantifying and valuing the ecosystem services of coastal lagoons. J. Nat. Conserv. doi:10.1016/j.jnc.2018.02.009 
Newton, A., Icely, J., Cristina, S., Brito, A., Cardoso, A.C., Colijn, F., Riva, S.D., Gertz, F., Hansen, J.W., Holmer, M., Ivanova, K., Leppäkoski, E., Canu, D.M., Mocenni, C., Mudge, S., Murray, N., Pejrup, M., Razinkovas, A., Reizopoulou, S., Pérez-Ruzafa, A., Schernewski, G., Schubert, H., Carr, L., Solidoro, C., PierluigiViaroli, Zaldívar, J.M., 2014. An overview of ecological status, vulnerability and future perspectives of European large shallow, semi-enclosed coastal systems, lagoons and transitional waters. Estuar. Coast. Shelf Sci. 140, 95-122. doi:10.1016/j.ecss.2013.05.023

Newton, A., Icely, J.D., Falcao, M., Nobre, A., Nunes, J.P., Ferreira, J.G., Vale, C., 2003. Evaluation of eutrophication in the Ria Formosa coastal lagoon, Portugal. Cont. Shelf Res. 23, 1945-1961. doi:10.1016/j.csr.2003.06.008

Ní Longphuirt, S., Mockler, E.M., O’Boyle, S., Wynne, C., Stengel, D.B., 2016. Linking changes in nutrient source load to estuarine responses: an Irish perspective. Biol. Environ. Proc. R. Irish Acad. 116B, 295. doi:10.3318/bioe.2016.21

Nixon, S.W., 1995. Coastal marine eutrophication: A definition, social causes, and future concerns. Ophelia 199-2019. doi:10.1080/00785236.1995.10422044

Oviatt, C., Smith, L., Krumholz, J., Coupland, C., Stoffel, H., Keller, A., McManus, M.C., Reed, L., 2017. Managed nutrient reduction impacts on nutrient concentrations, water clarity, primary production, and hypoxia in a north temperate estuary. Estuar. Coast. Shelf Sci. 199, 25-34. doi:10.1016/j.ecss.2017.09.026

Pasqualini, V., Derolez, V., Garrido, M., Orsoni, V., Baldi, Y., Etourneau, S., Leoni, V., Rébillout, P., Laugier, T., Souchu, P., Malet, N., 2017. Spatiotemporal dynamics of submerged macrophyte status and watershed exploitation in a Mediterranean coastal lagoon: Understanding critical factors in ecosystem degradation and restoration. Ecol. Eng. 102, 1-14. doi:10.1016/j.ecoleng.2017.01.027

Péna, G., Picot, B., 1991. Métaux traces dans les sédiments d'une lagune méditerranéenne: l'étang de Thau. Oceanol. Acta 14, 459-472.

Pérez-Ruzafa, A., Campillo, S., Fernández-Palacios, J.M., García-Lacunza, A., García-Oliva, M., Ibañez, H., Navarro-Martínez, P.C., Pérez-Marcos, M., Pérez-Ruzafa, I.M., Quispe-Becerra, J.I., Sala-Mirete, A., Sánchez, O., Marcos, C., 2019a. Long-term dynamic in nutrients, Chlorophyll a, 
and water quality parameters in a coastal lagoon during a process of eutrophication for decades, a sudden break and a relatively rapid recovery. Front. Mar. Sci. 6, 1-24. doi:10.3389/fmars.2019.00026

Pérez-Ruzafa, A., Pérez-Ruzafa, I.M., Newton, A., Marcos, C., 2019b. Coastal lagoons: environmental variability, ecosystem complexity, and goods and services uniformity, in: Wolanski, E., Day, J.W., Elliott, M., Ramachandran, R. (Eds.), Coasts and Estuaries. The Future. pp. 253-276. doi:10.1016/b978-0-12-814003-1.00015-0

Pernet, F., Barret, J., Gall, P. Le, Corporeau, C., Dégremont, L., Lagarde, F., Pépin, J., Keck, N., 2012. Mass mortalities of Pacific oysters Crassostrea gigas reflect infectious diseases and vary with farming practices in the Mediterranean Thau lagoon, France. 2: 215-237. doi:10.3354/aei00041

Pernet, F., Lagarde, F., Le Gall, P., Roque D'Orbcastel, E., 2014. Associations between farming practices and disease mortality of Pacific oyster Crassostrea gigas in a Mediterranean lagoon. Aquac. Environ. Interact. 5, 99-106. doi:10.3354/aei00096

Pernet, F., Fuhrmann, M., Petton, B., Mazurié, J., Bouget, J.F., Fleury, E., Daigle, G., Gernez, P., 2018. Determination of risk factors for herpesvirus outbreak in oysters using a broad-scale spatial epidemiology framework. Sci. Rep. 8, 1-11. doi:10.1038/s41598-018-29238-4

Pete, R., Guyondet, T., Bec, B., Derolez, V., Cesmat, L., Lagarde, F., Pouvreau, S., Fiandrino, A., Richard, M. 2020. A box-model of carrying capacity of the Thau lagoon in the context of ecological status regulations and sustainable shellfish cultures. Ecol. Mod. (426). https://doi.org/10.1016/j.ecolmodel.2020.109049

Picot, B., Péna, G., Casellas, C., Bondon, D., Bontoux, J., 1990. Interpretation of the seasonal variations of nutrients in a mediterranean lagoon: étang de Thau. Hydrobiologia 207, 105-113. doi:10.1007/BF00041446

Plus, M., Chapelle, A., Lazure, P., Auby, I., Levavasseur, G., Verlaque, M., Belsher, T., Deslous-Paoli, J.M., Zaldívar, J.M., Murray, C.N., 2003. Modelling of oxygen and nitrogen cycling as a function of macrophyte community in the Thau lagoon. Cont. Shelf Res. 23, 1877-1898. doi:10.1016/j.csr.2003.03.001 
Pulina, S., Satta, C.T., Padedda, B.M., Sechi, N., Lugliè, A., 2018. Seasonal variations of phytoplankton size structure in relation to environmental variables in three Mediterranean shallow coastal lagoons. Estuar. Coast. Shelf Sci. 212, 95-104. doi:10.1016/j.ecss.2018.07.002

Ratmaya, W., Soudant, D., Salmon-Monviola, J., Cochennec-Laureau, N., Goubert, E., AndrieuxLoyer, F., Barillé, L., Souchu, P., 2018. Reduced phosphorus loads from the Loire and Vilaine Rivers were accompanied by increasing eutrophication in Vilaine Bay (South Brittany, France). Biogeosciences Discuss. 1-29. doi:10.5194/bg-2018-406

Riemann, B., Carstensen, J., Dahl, K., Fossing, H., Hansen, J.W., Jakobsen, H.H., Josefson, A.B., Krause-Jensen, D., Markager, S., Stæhr, P.A., Timmermann, K., Windolf, J., Andersen, J.H., 2016. Recovery of Danish Coastal Ecosystems After Reductions in Nutrient Loading: A Holistic Ecosystem Approach. Estuaries and Coasts 39, 82-97. doi:10.1007/s12237-015-9980-0

Scheffer, M., Carpenter, S.R., 2003. Catastrophic regime shifts in ecosystems: linking theory to observation. Trends Ecol. Evol. 18, 648-656. doi:10.1016/j.tree.2003.09.002

Schmidt, S., Bernard, C., Escalier, J.M., Etcheber, H., Lamouroux, M., 2017. Assessing and managing the risks of hypoxia in transitional waters: a case study in the tidal Garonne River (South-West France). Environ. Sci. Pollut. Res. 24, 3251-3259. doi:10.1007/s11356-016-7654-5

Schramm, W., 1999. Factors influencing seaweed responses to eutrophication : some results from EUproject EUMAC. J. Appl. Phycol. 11, 69-78.

Schwarz, G., 1978. Estimating the Dimension of a Model. Annals of Statistics 6, 461-464.

Sen, P.K. 1968. Estimates of the regression coefficient based on Kendall's tau, Journal of the American Statistical Association, 63 (324): 1379-1389. doi:10.2307/2285891.

Søndergaard, M., Jensen, J.P., Jeppesen, E., 2003. Role of sediment and internal loading of

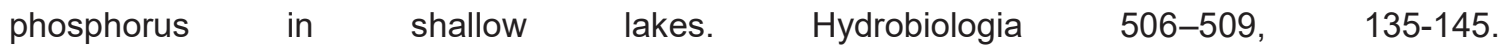
doi:10.1023/B:HYDR.0000008611.12704.dd

Souchu, P., Bec, B., Smith, V.H., Laugier, T., Fiandrino, A., Benau, L., Orsoni, V., Collos, Y., Vaquer, A., 2010. Patterns in nutrient limitation and chlorophyll a along an anthropogenic eutrophication gradient in French Mediterranean coastal lagoons. Can. J. Fish. Aquat. Sci. 67, 743-753. doi:10.1139/F10-018 
Souchu, P., Vaquer, A., Collos, Y., Landrein, S., Bibent, B., 2001. Influence of shellfish farming activities on the biogeochemical composition of the water column in Thau lagoon. Mar. Ecol. Prog. Ser. 218, 141-152. doi:10.3354/meps218141

Souchu, P., Gasc, A., Collos, Y., Vaquer, A., Tournier, H., Bibent, B., Deslous-Paoli, J., 1998. Biogeochemical aspects of bottom anoxia in a Mediterranean lagoon (Thau, France). Mar. Ecol. Prog. Ser. 164, 135-146. doi:10.3354/meps164135

Swets, J.A., 1988. Measuring the accuracy of diagnostic systems. Science, 3, 240(4857): 1285-93. doi:10.1126/science.3287615

Testa, J.M., Li, Y., Lee, Y.J., Li, M., Brady, D.C., Di Toro, D.M., Kemp, W.M., Fitzpatrick, J.J., 2014. Quantifying the effects of nutrient loading on dissolved O2 cycling and hypoxia in Chesapeake Bay using a coupled hydrodynamic-biogeochemical model. J. Mar. Syst. 139, 139-158. doi:10.1016/j.jmarsys.2014.05.018

Trombetta, T., Vidussi, F., Mas, S., Parin, D., Simier, M., Mostajir, B., 2019. Water temperature drives phytoplankton blooms in coastal waters. PLoS One 14, 1-28. doi:10.1371/journal.pone.0214933

Troussellier, M., Deslous-Paoli, J.M., 2001. La lagune de Thau: un site atelier pour l'acquisition, l'intégration et la valorisation des connaissances. Oceanis 27, 257-289.

Tsiamis, K., Panayotidis, P., Salomidi, M., Pavlidou, A., Kleinteich, J., Balanika, K., Küpper, F.C., 2013. Macroalgal community response to re-oligotrophication in Saronikos Gulf. Mar. Ecol. Prog. Ser. 472, 73-85. doi:10.3354/meps 10060

Verbeek, L., Gall, A., Hillebrand, H., Striebel, M., 2018. Warming and oligotrophication cause shifts in freshwater phytoplankton communities. Glob. Chang. Biol. 24, 4532-4543. doi:10.1111/gcb.14337

Verlaque, M., 2000. Actualisation de la flore des macrophytes des étangs de Thau (Hérault) et de Salses-Leucate (Aude-Pyrénées-Orientales). In: PNEC “Lagunes Méditerranéennes", Thème 1, le compartiment "Macrophytes". GIS Posidonie - IFREMER Report, Marseille. 64 p. + annexes. Report in French.

Viaroli, P., Bartoli, M., Giordani, G., Naldi, M., 2008. Community shifts, alternative stable states, biogeochemical controls and feedbacks in eutrophic coastal lagoons : a brief overview. Aquat. 
Conserv. Mar. Freshw. Ecosyst. 18, 105-117. doi:10.1002/aqc

Zaldívar, J.-M., Cardoso, A.C., Viaroli, P., Wit, R. De, Ibañez, C., Reizopoulou, S., Razinkovas, A., Basset, A., Holmer, M., Murray, N., 2008. Eutrophication in transitional waters : an overview. TWM, Transit. Waters Monogr. 1, 1-78. doi:10.1285/i18252273v2n1p1

Zilius, M., Giordani, G., Petkuviene, J., Lubiene, I., Ruginis, T., Bartoli, M., 2015. Phosphorus mobility under short-term anoxic conditions in two shallow eutrophic coastal systems (Curonian and Sacca di Goro lagoons). Estuar. Coast. Shelf Sci. 164, 134-146. doi:10.1016/j.ecss.2015.07.004 
Fig. 1. A) Location of Thau lagoon and of water and macrophyte sampling stations (*the macrophyte station not sampled in 2003). B) Location of sediment sampling stations. The three shellfish farming areas are represented by polygons.

Fig. 2. Changes in summer DIP concentrations $(\mu \mathrm{M})$ in the water in Thau lagoon from 1972 to 2018 at ZA station (1972-1993) and TE station (1999-2018). Data for June are represented by black dots and the LOESS curve in DIP in June by a black line. Data for July and August are represented by grey dots. The blue line represents the threshold of the good status according to the WFD (DIP $\leq 1 \mu \mathrm{M}$; MTES, 2018).

Fig. 3. Results of PCA analysis of water column parameters monitored from 1999 to 2018 at the three stations TW, TE and TANG. A) First and second axes for the nine environmental variables (dissolved inorganic nitrogen (DIN), dissolved inorganic phosphorus (DIP), total phosphorus (TP), total nitrogen (TN), chlorophyll a (CHLA), autotrophic picoeukaryotes (PEUK), nanophytoplankton (NANO), phycoerythrin-rich picocyanobacteria (PE-CYAN) and dissolved oxygen (O2)). Illustrative hydrological variables (temperature (TEMP), salinity (SAL) and turbidity (TURB)) are in blue. B) Years and C) sampling stations on the plane defined by first and second axes accounted for $52.6 \%$ of the total variability. The first cluster is represented by a grey ellipse and the second cluster by a black ellipse.

Fig. 4. Changes in mean summer chlorophyll a biomass $\left(\mu \mathrm{g}\right.$ Chla $\left.\mathrm{L}^{-1}\right)(A)$, nanophytoplankton $(B)$, picoeukaryote $(C)$ and phycoerythrin-rich picocyanobacteria abundances $\left(10^{6}\right.$ cells $\left.L^{-1}\right)$ with changes in water temperature $\left({ }^{\circ} \mathrm{C}\right)$ (D) from 1999 to 2018 at TW and TE (averaged) and TANG stations (respectively in blue and orange).

Fig. 5. Proportion of stations dominated by four groups of macrophytes (seagrass, brown algae, red algae and green algae) or bare sediment from 1966 to 2017 (data from Bouchoucha et al. 2019; Derolez et al. 2015; Dubois 1972; Gerbal and Verlaque 1995; Ifremer 2004, 2009 \& 2012; Lauret 1967, 1970, 1990 \& 1994; Verlaque, 2000). NB: 1966 refers to the sampling period 1963-1968; 1992 refers to the sampling period 1988-1994.

Fig. 6. Oyster (in brown), mussel (in grey) and total shellfish production (in black) in $10^{3} \mathrm{t} \mathrm{year}^{-1}$ from 1970 to 2018 and the occurrence of summer anoxia events (vertical grey bands) in Thau lagoon. 
Fig. 7. Duration and intensity of summer anoxia crises from 1970 to 2018 . The $y$-axis corresponds to the duration (months) of the crises and the size of the bubbles corresponds to the spatial extent of the anoxia.

Fig. 8. Effects of the 3 meteorogical variables included in the glm predicting the probability of triggering summer anoxia (\%: mean and confidence interval): wind intensity (wind_ST, standardised unit), air temperature (air_M, ${ }^{\circ} \mathrm{C}$ ), rainfall in July (rainfall_7, mm), based on the period determined according to the eutrophication status (period 1 or period 2).

Fig. 9. Schematic synthesis of the oligotrophication process in Thau lagoon from 1970 to 2018 (period 1 and the 3 steps in period 2) and a possible scenario for the period 2020-2030 (stabilization of the nutrient load and increase in temperature). Pressures: nutrient inputs from the watershed and climate driver (temperature). Impact: the size of the bubbles represents the spatial extent and the intensity of the colour grey the intensity of the summer anoxia crises. Changes in mussel and oyster production: the size of the shellfish represents the level of production. Abundance of DIP and $\mathrm{Chl} a$ in the lagoon water and the abundance of seagrass, green algae and red algae in the soft-bottom sediment. Ecosystem status: the eutrophication status of the water column according to the WFD thresholds determined for DIP in French coastal lagoons (MTES, 2018). All variables are represented within relative space. 


\section{Author Contribution Statement :}

Valérie Derolez : Conceptualization ; Data curation ; Formal analysis; Funding acquisition; Methodology; Project administration; Supervision; Writing - original draft; Writing - review \& editing.

Nathalie Malet : Writing - review \& editing; Funding acquisition; Methodology; Validation; Project administration.

Annie Fiandrino : Methodology; Validation; Writing - review \& editing.

Franck Lagarde : Validation; Writing - review \& editing.

Marion Richard : Validation; Writing - review \& editing.

Vincent Ouisse : Data curation; Validation; Writing - review \& editing.

Béatrice Bec : Formal analysis; Methodology; Writing - original draft ; Writing - review \& editing.

Catherine Aliaume : Methodology; Validation; Writing - review \& editing 


\section{Declaration of competing interests}

The authors declare that they have no known competing financial interests or personal relationships that could have appeared to influence the work reported in this paper. 
Graphical abstract

\section{Highlights:}

- This 5-decades study explains the oligotrophication trajectory of a coastal lagoon

- The decrease in nutrient inputs resulted in ecological changes in pelagic \& benthic communities

- A eutrophic period, a transition phase $\&$ a regime shift characterised recovery

- The main triggers of summer anoxia were air temperature and eutrophication status

- Oligotrophication has made the ecosystem more resistant to the threat of heat waves 

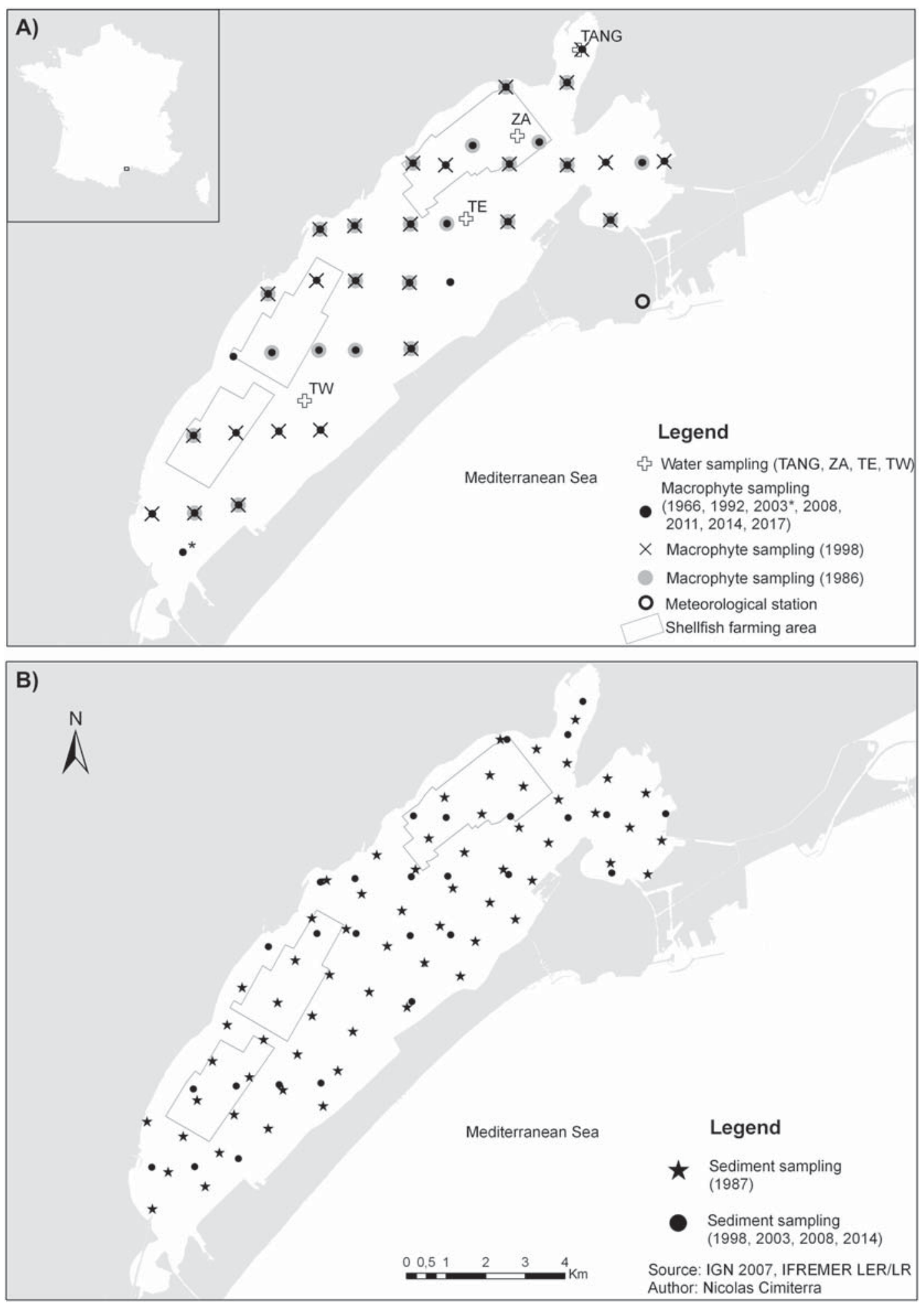

Figure 1 


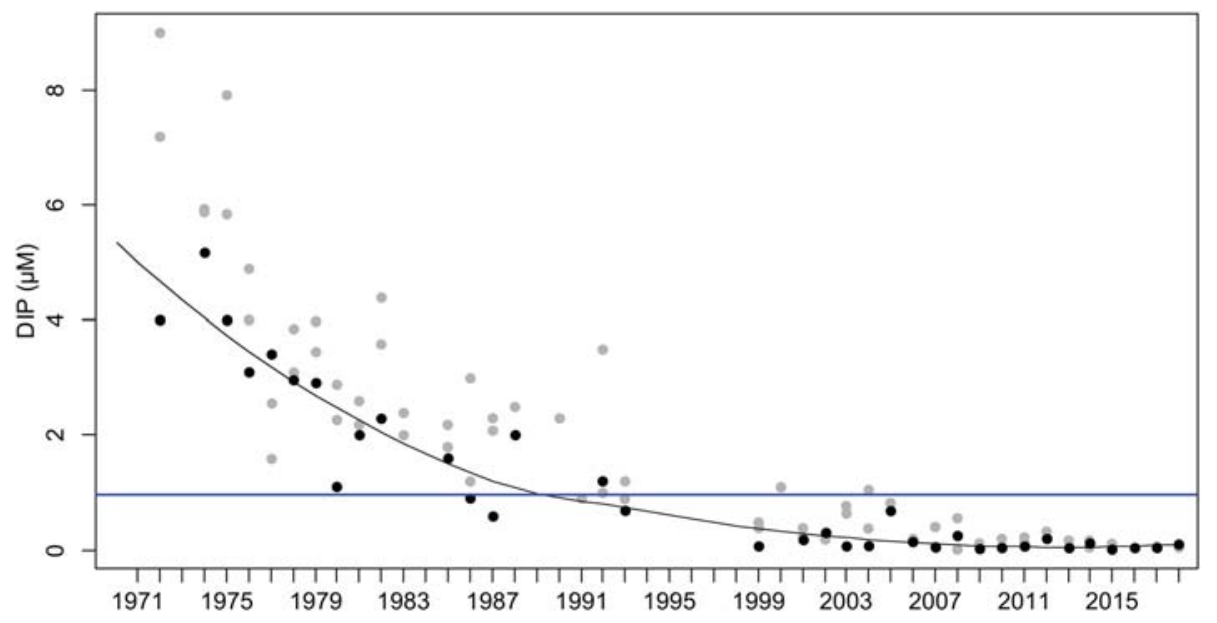

Figure 2 

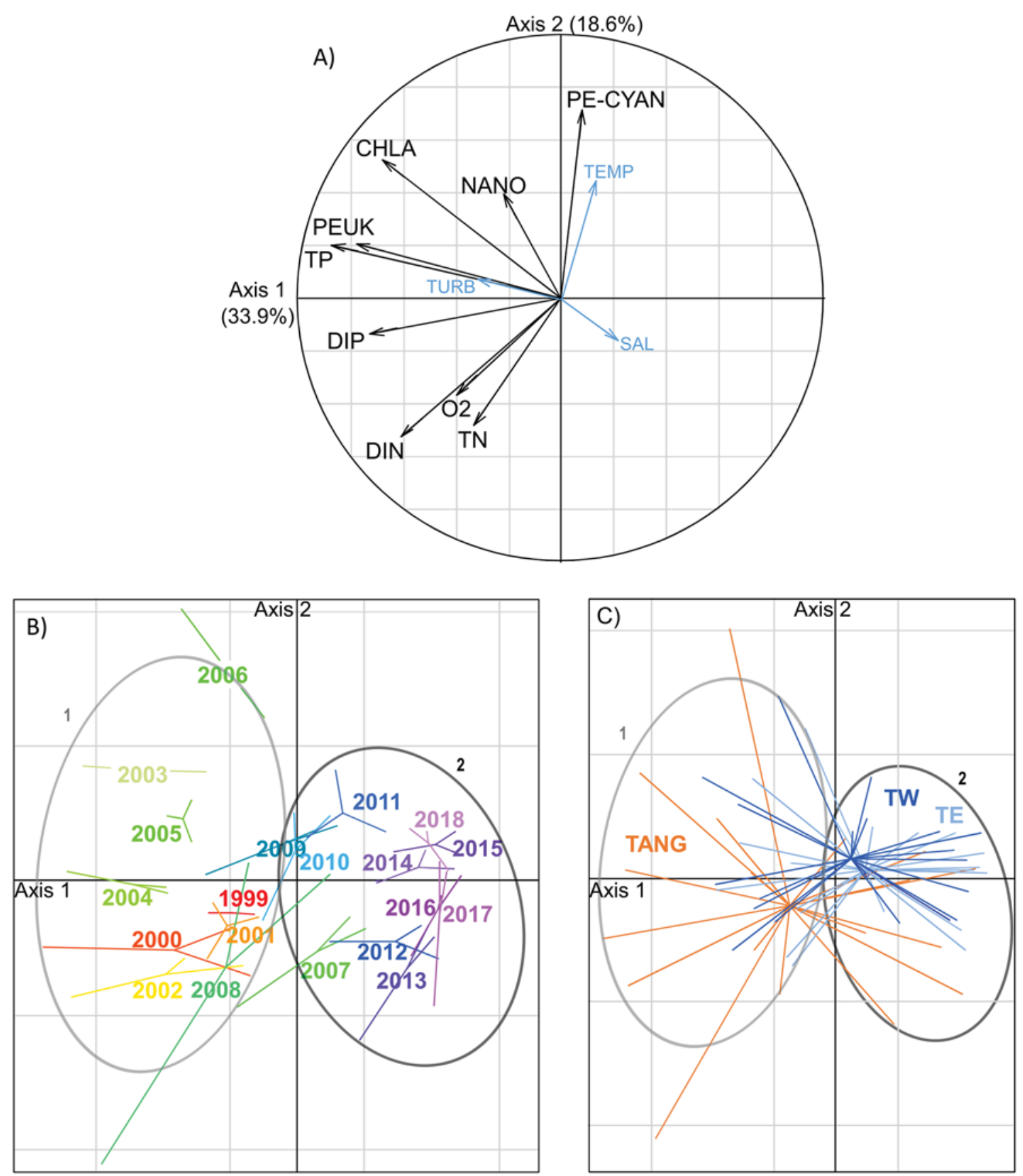

Figure 3 

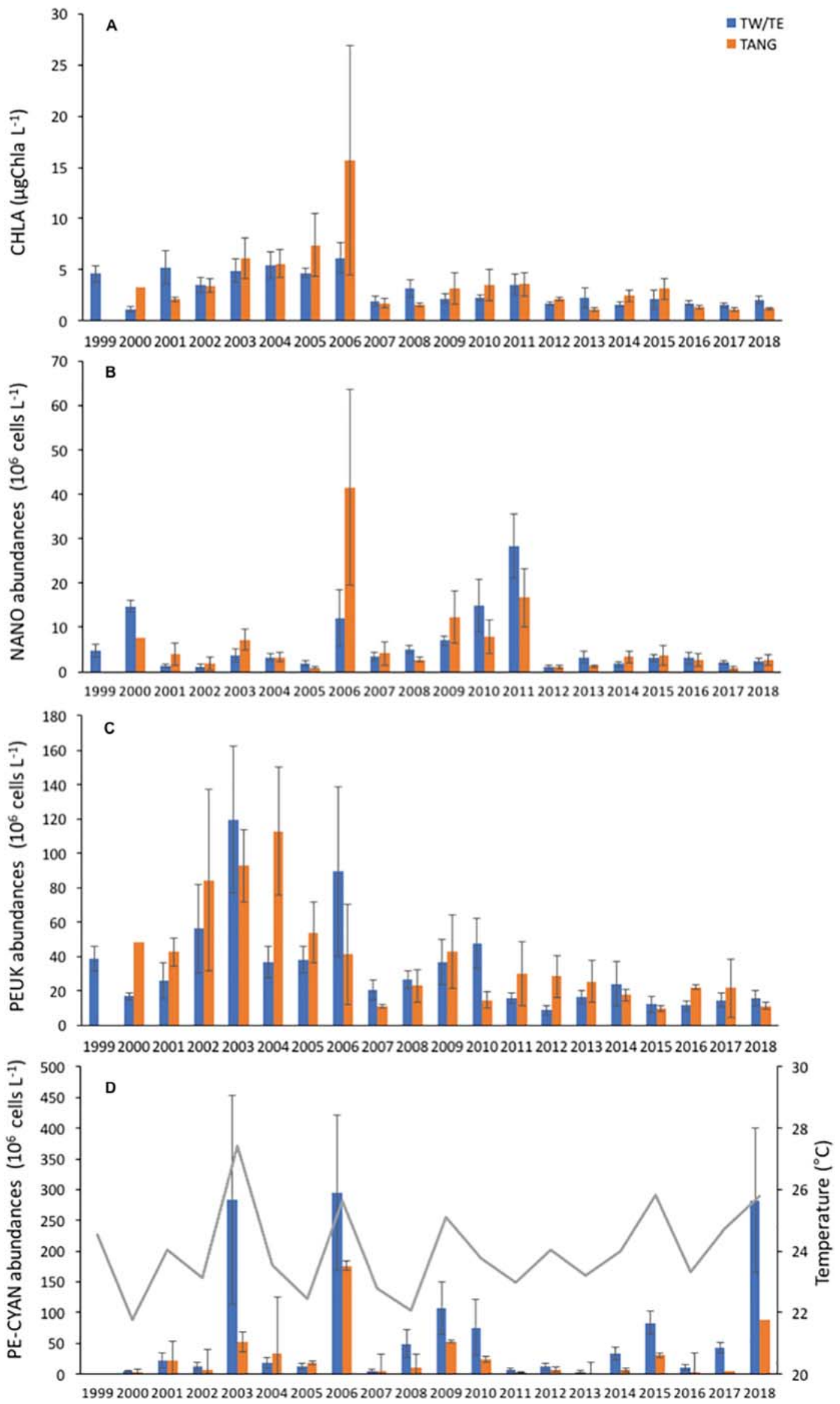

Figure 4 


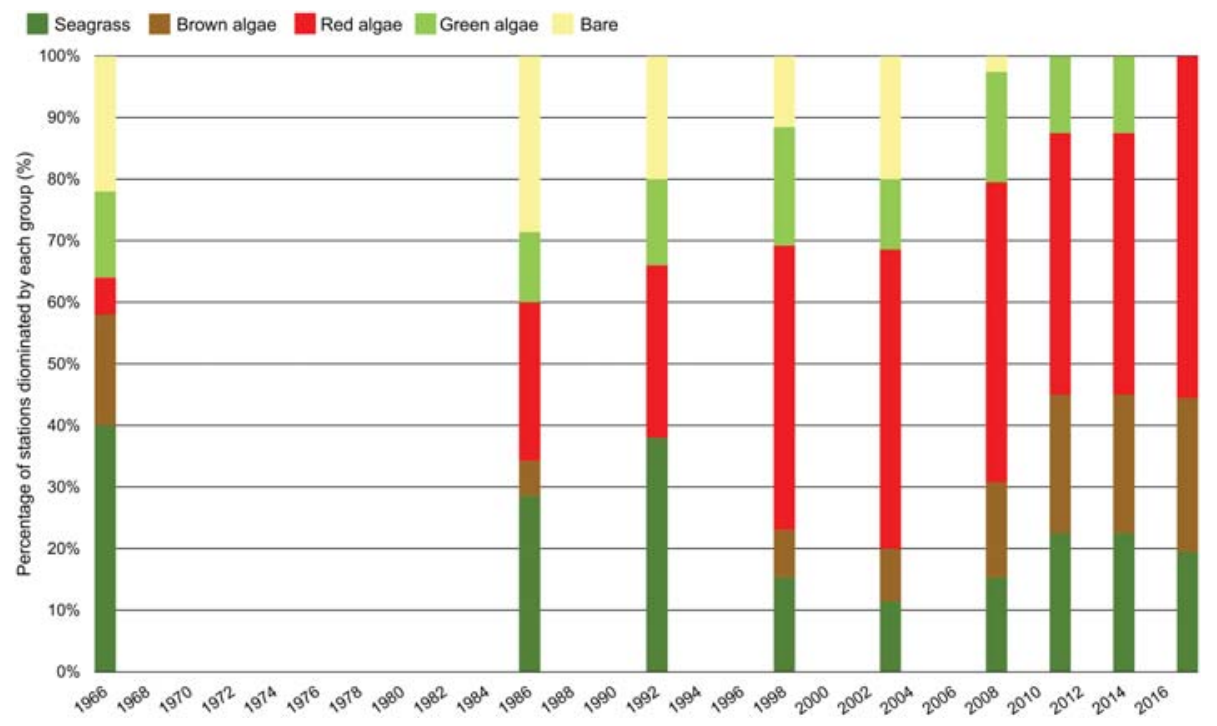

Figure 5 


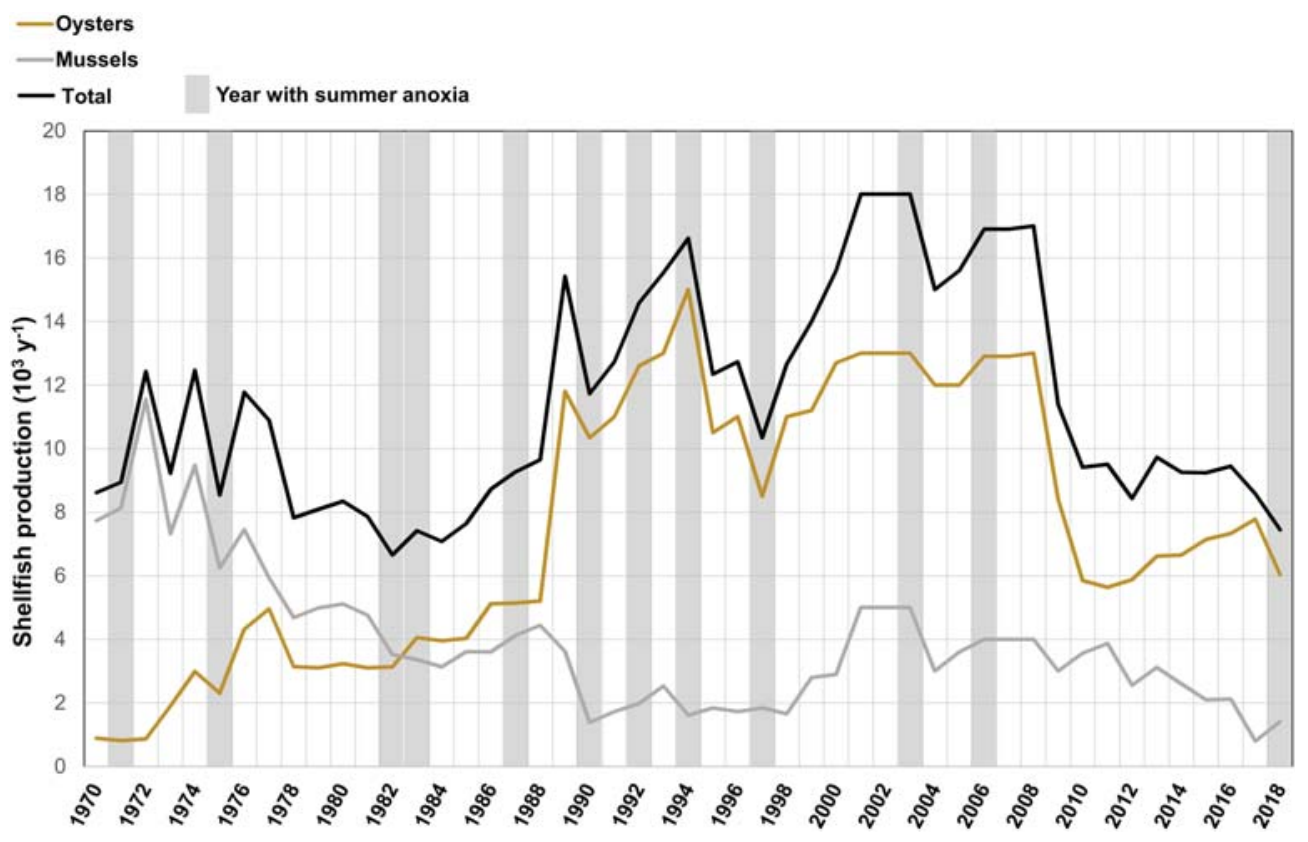

Figure 6 


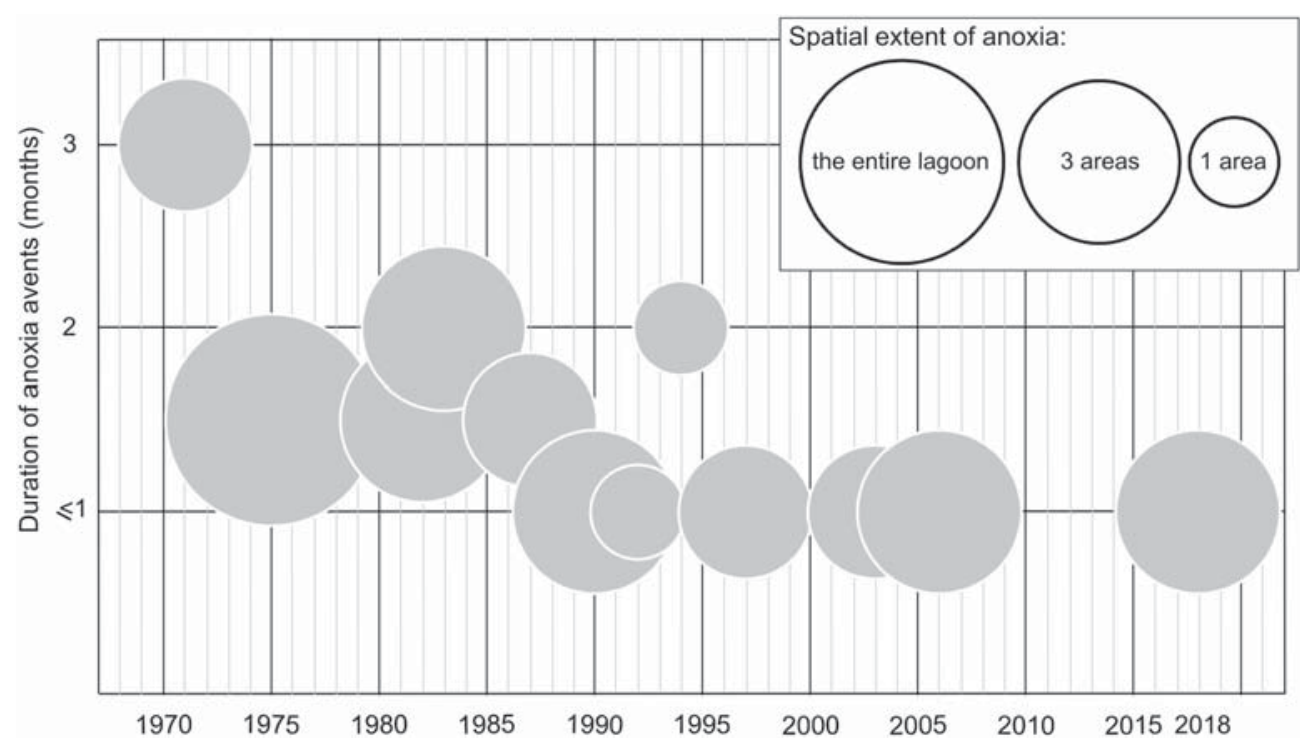

Figure 7 

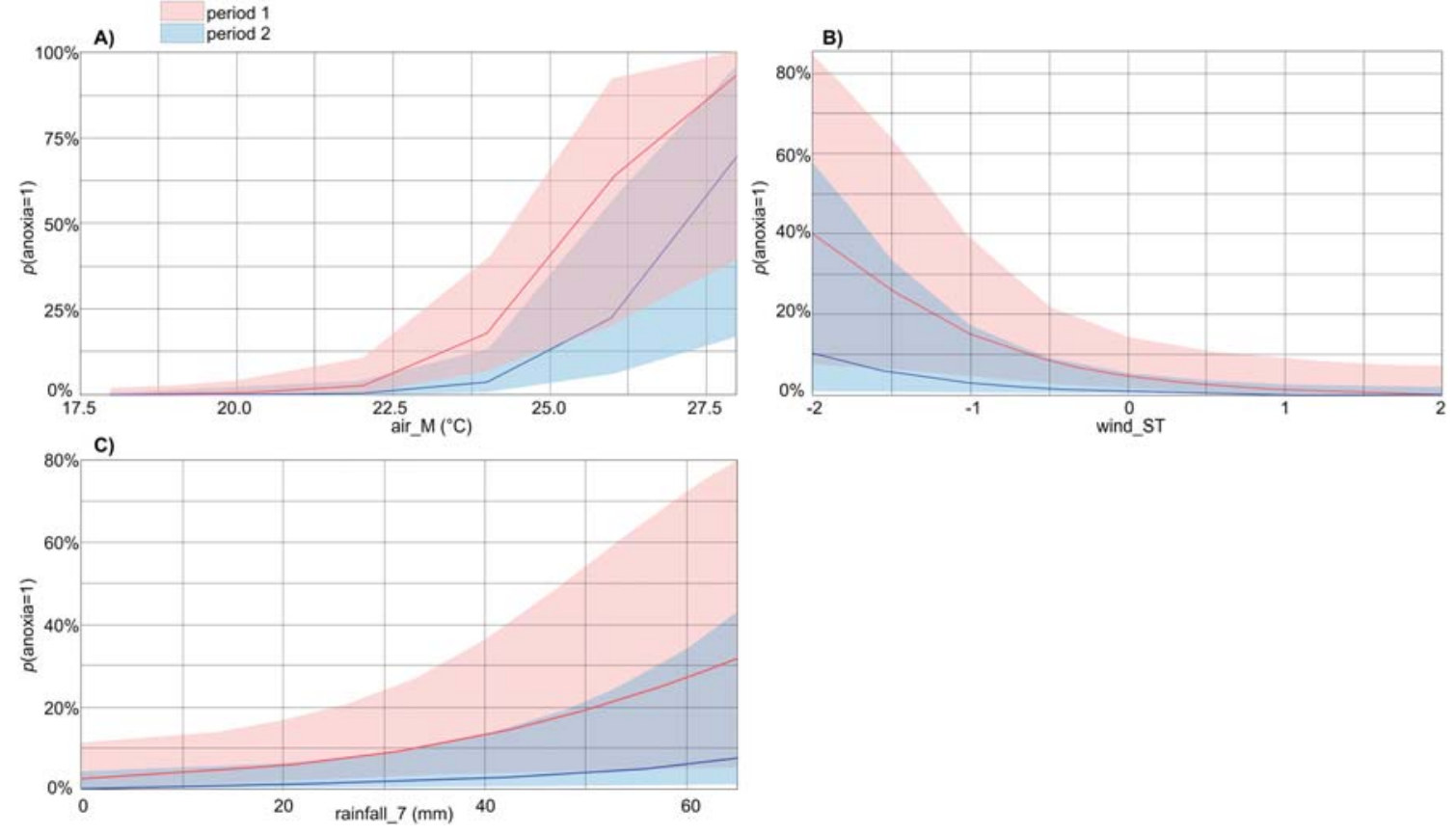

Figure 8 


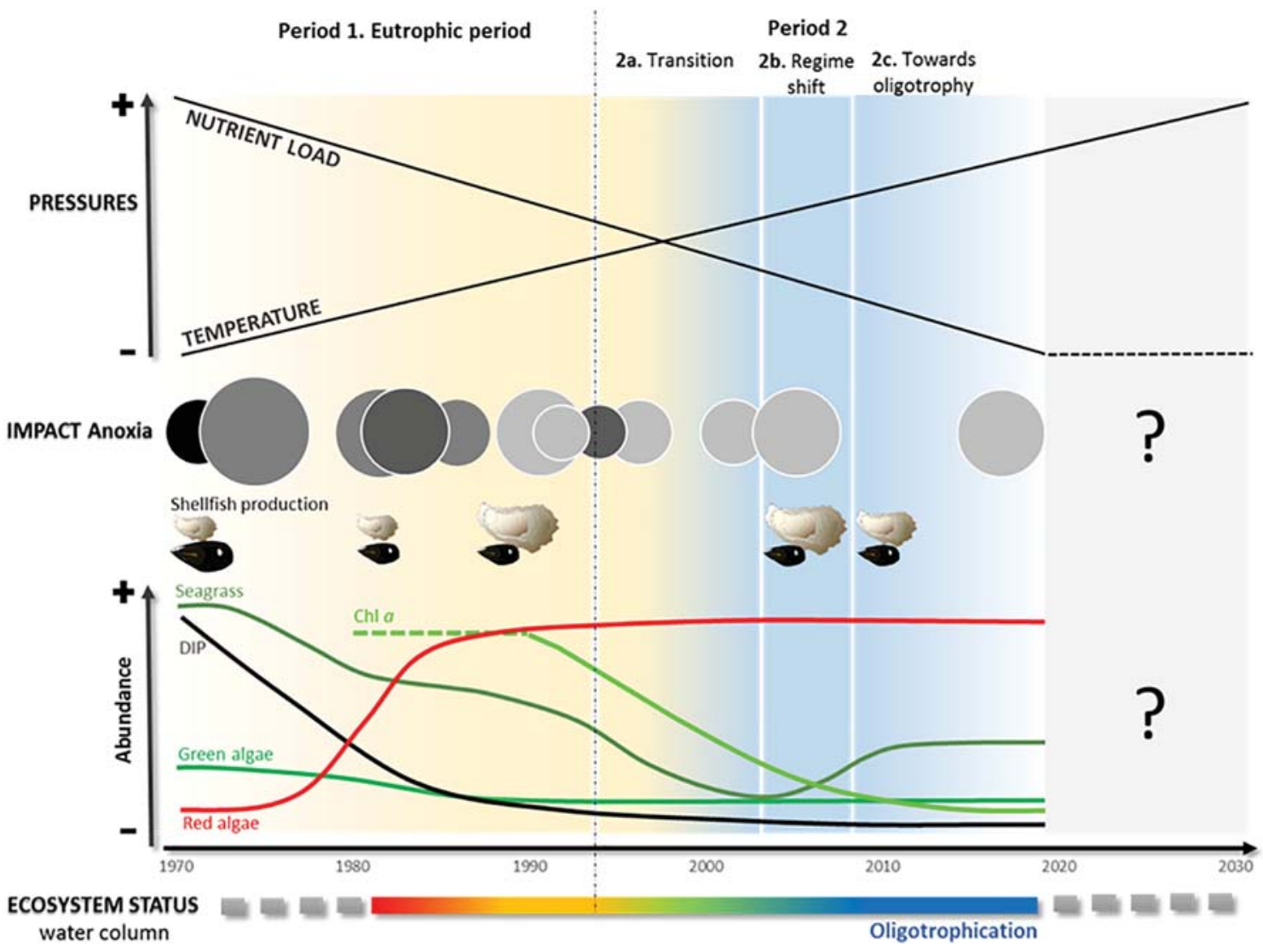

Figure 9 